\title{
Applications of the Open-Source Hardware Arduino Platform in the Mining Industry: A Review
}

\author{
Sung-Min Kim ${ }^{1}$, Yosoon Choi ${ }^{2, *(1)}$ and Jangwon Suh ${ }^{1}[$ \\ 1 Department of Energy Engineering, Kangwon National University, Samcheok 25913, Korea; \\ smkim19@kangwon.ac.kr (S.-M.K.); jangwonsuh@kangwon.ac.kr (J.S.) \\ 2 Department of Energy Resources Engineering, Pukyong National University, Busan 48513, Korea \\ * Correspondence: energy@pknu.ac.kr; Tel.: +82-51-629-6562
}

Received: 17 June 2020; Accepted: 15 July 2020; Published: 21 July 2020

\begin{abstract}
In this study, applications of the Arduino platform in the mining industry were reviewed. Arduino, a representative and popular open-source hardware, can acquire information from various sensors, transmit data using communication technology, and control devices through actuators. The review was conducted by classifying previous studies into three types of Arduino applications: field monitoring systems, wearable systems, and autonomous systems. With regard to field monitoring systems, most studies in mines were classified as atmospheric or geotechnical monitoring. In wearable systems, the health status of the miner was an important consideration, in addition to the environmental conditions of the mine. Arduino can be a useful tool as an initial prototype for autonomous mine systems. Arduino has advantages in that it can be combined with various electronic products and is cost-effective. Therefore, although many studies have been conducted in the laboratory (as opposed to field tests), Arduino applications can be further expanded in the mining field in the future.
\end{abstract}

Keywords: open-source hardware; Arduino; monitoring; wearable; autonomous system

\section{Introduction}

In the fourth industrial revolution, information and communication technologies such as the Internet of Things (IoT), artificial intelligence, big data, 3D printing, and robotics have played important roles in various fields. To increase safety and productivity in the mining industry, smart mining technologies combining the above-mentioned technologies have been developed [1,2]. Mining equipment, such as drills, trucks, shovels, and conveyors, can be automated, and various valuable data can be collected from them. However, they are expensive and difficult to use in small mining companies. Therefore, recently, attempts have been made to utilize inexpensive open-source technology for mining. Open-source technology has provided key building blocks for interoperability and flexibility and is expected to play a key role in the future [3]. Since the 90s, the term "open-source" has been used to describe free software, i.e., the public can use the source code freely [4]. Many open-source organizations, such as the Apache Software Foundation, Linux Professional Institute, Eclipse Foundation, and Mozilla Foundation, have successfully used open-source technology in industry [5]. Recently, in addition to open-source software, open-source hardware has also been employed in various fields, including the mining industry. Open-source hardware refers to the design specifications of a physical object that can be studied, modified, produced, and distributed by anyone [6]. With permissive licenses, open-source hardware can be freely redistributed and modified, helping manufacturers to accelerate design and improve interoperability, by supporting faster prototyping and customization of reprogrammable components [7]. In addition, open-source hardware can be a low-cost alternative to scientific instrumentation and research requiring the collection of data for a particular process or event [8]. 
Open-source hardware has been used in many sectors, such as in education [9-11], agriculture [12-18], ecology $[19,20]$, and energy $[8,21]$ and is continuously expanding, owing to its advantages regarding self-development objectives and higher cost efficiencies [22]. Numerous open-source hardware projects exist in sectors such as computer systems, communications, robotics, machines and production tools, and science, as shown in Table 1 [23]. In particular, there are many types of open-source computing hardware related to computer systems. [24]. Therefore, it is impossible to manage all types of open-source hardware. Accordingly, this study targets Arduino, one of the most popular open-source computing hardware platforms.

Table 1. Examples of open-source hardware projects [23].

\begin{tabular}{|c|c|c|c|c|}
\hline Computer Systems & Communications & Robotics & $\begin{array}{l}\text { Machines and } \\
\text { Production Tools }\end{array}$ & Science \\
\hline $\begin{array}{ll}\text { - } & \text { Arduino } \\
\text { - } & \text { Chumby } \\
\text { - } & \text { CUBIT } \\
\text { - } & \text { Libre } \\
& \text { Computer Project } \\
\text { - } & \text { Netduino } \\
\text { - } & \text { NodeMCU } \\
\text { - } & \text { Novena } \\
\text { - } & \text { Parallax Propeller } \\
\text { - } & \text { Parallella } \\
\text { - } & \text { SparkFun } \\
& \text { Electronics }\end{array}$ & $\begin{array}{ll}\text { - } & \text { NetFPGA } \\
\text { - } & \text { OpenBTS } \\
\text { - } & \text { Openmoko } \\
\text { - } & \text { Openpicus } \\
\text { - } & \text { PiPhone } \\
& \text { and ZeroPhone } \\
\text { - } & \text { PowWow } \\
\text { - } & \text { Project Ara } \\
\text { - } & \text { SatNOGS } \\
\text { - } & \text { Sun SPOT } \\
\text { - } & \text { Twibright RONJA } \\
\text { - } & \text { USRP }\end{array}$ & $\begin{array}{ll}\text { - } & \text { ArduCopter } \\
\text { - } & \text { e-puck } \\
\text { - } & \text { ICubile robot } \\
\text { - } & \text { IOIO } \\
\text { - } & \text { multiplo } \\
\text { - } & \text { Orb swarm } \\
\text { - } & \text { OpenRAVE } \\
\text { - } & \text { OpenROV } \\
\text { - } & \text { RobotCub } \\
\text { - } & \text { Spykee } \\
\text { - } & \text { Thymio } \\
\text { - } & \text { Tinkerforge }\end{array}$ & $\begin{array}{ll}\text { - } & \text { LulzBot } \\
\text { - } & \text { MakerPlane } \\
\text { - } & \text { Multimachine } \\
\text { - } & \text { OpenXC } \\
\text { - } & \text { OScar } \\
\text { - } & \text { OSVehicle Tabby } \\
\text { - } & \text { Precious Plastic's } \\
\text { - } & \text { Rally Fighter } \\
\text { - } & \text { RepRap project } \\
\text { - } & \text { Riversimple } \\
\text { - } & \text { Urban Car } \\
\text { Wikispeed }\end{array}$ & $\begin{array}{ll}\text { - } & \text { Open } \\
& \text { Prosthetics Project } \\
\text { - } & \text { Open-source } \\
& \text { ventilator } \\
\text { - } & \text { Open-Source Lab } \\
\text { - } & \text { OpenBCI }\end{array}$ \\
\hline
\end{tabular}

Arduino is an open-source electronics platform created at the Ivrea Interaction Design Institute. It consists of a programmable microcontroller mounted on a circuit board. Arduino can convert input information obtained from a connected sensor to output and extend functionality through add-on boards called "shields." It can perform physical control by using an actuator such as a motor or light-emitting diode (LED). Arduino is relatively inexpensive compared to other microcontroller platforms and is sufficiently versatile to run on Windows, Macintosh OSX, and Linux operating systems [25]. The language of Arduino software can be extended through C++ libraries, and the Arduino hardware is also extensible, i.e., users can develop their own version of the module. As a result, researchers have made low-cost instruments suitable for their needs by utilizing the Arduino platform.

Recently, the research and development of products for IoT applications, wearables, and automation using the Arduino board have been increasing in the mining industry [26,27]. For example, Jo and Khan [28] monitored the environment of an underground mine by connecting gas, temperature, and humidity sensors to an Arduino Mega and installing them on site. The results were transmitted to a base station via Bluetooth low energy (BLE). In addition, the BLE-based Arduino Mega board was used to track the location of a miner, in connection with a mobile node. Arduino can play important roles in wearable systems, e.g., in recognizing the condition of mine workers, as well as environmental information in mines. Alam et al. [29] designed a prototype intelligent helmet using Arduino Mega for heart rate and air quality monitoring. Information such as the mine worker's heart rate and the gas, temperature, and humidity inside the mine was obtained from the sensors of the intelligent helmet. The results were transferred to a storage device using the ZigBee module and could be used to provide an alarm through a screen and/or buzzer. The number of Arduino applications in autonomous systems is also increasing. Sakthi et al. [30] used Arduino UNO to automate bucket control for a load haul dumper (LHD). The bucket control module controlled a bucket actuator after detecting forces in the boom using a pressure sensor connected to the Arduino UNO. Although many studies have been conducted, no use cases for the Arduino open-source hardware platform in the mining industry have been reviewed.

Therefore, the purpose of this study is to review the Arduino applications currently used in the mining industry. Keywords (e.g., Arduino, open-source hardware, underground mine, or open-pit 
mine) were input into the websites of Google Scholar, SCOPUS, and the Web of Science to search for published literature, and 73 articles were found in the first stage. After excluding papers with duplicate content or articles with poor quality, 48 articles were selected for review. Figure 1 shows the literature search process. Although there are many cases where open-source hardware has been used in the mining industry in addition to Arduino, it is impossible to investigate all research related to open-source hardware owing to the wide range of products. Similarly, this study did not target smart mining itself, and the scope of this review was confined to published literature related to Arduino applications in the mining industry. Arduino-based research is currently being used in diverse applications; thus, it can best represent the overall trend. The reviewed literature was classified into studies on field monitoring, wearable systems, and autonomous systems, depending on what the Arduino was used for. This classification was also linked to the functional characteristics and purpose(s) of the Arduino application.

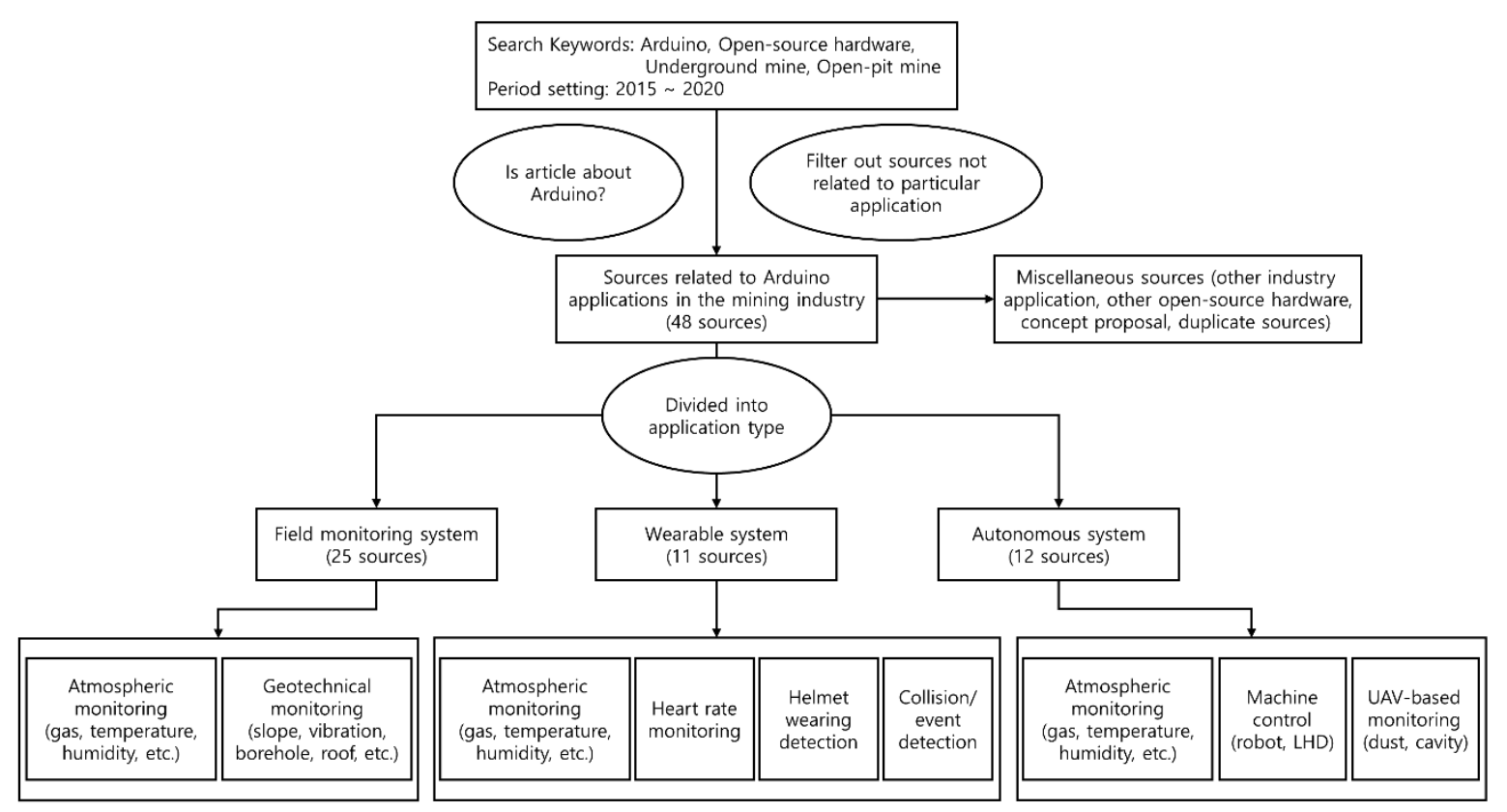

Figure 1. Process of literature search and classification.

The remainder of this paper is organized as follows. Section 2 describes studies in which Arduino is used in obtaining air quality data or geotechnical data at mining sites. Section 3 reviews how Arduino can be incorporated into wearable systems for various purposes at mine sites. Section 4 addresses studies involving Arduino related to automation, such as unmanned aerial vehicles (UAV) or unmanned robots. In Section 5, all of the papers reviewed in this study are statistically classified, and the trends are discussed according to purpose, mine type, Arduino type, sensor, communication, and actuator. Finally, Section 6 summarizes these articles and presents the implications of this study.

\section{Arduino in Field Monitoring Systems}

\subsection{Overview}

Mining operations are exposed to dangerous environments, regardless of whether they are underground mines or open-pit mines. In underground mines, workers can be exposed to toxic gases, and there is a risk of explosion and fire from coal dust. In addition, there is a risk of roof collapse in underground mines and risk of slope collapse in open-pit mines. Therefore, for safety, it is very important to continuously acquire atmospheric data and geotechnical data from the mine to detect dangers in advance. As Arduino can be combined with various sensors and communication technologies, it is very cost-effective and useful for data acquisition based on IoT technology. Based on 
the reviewed literature, air quality data is usually measured in underground mines, and geotechnical data is usually measured in open-pit mines. The types of monitoring systems discussed in each article are summarized in Table 2. Figure 2 depicts the applications of these monitoring systems according to the type of mine. The microcontrollers used in the reviewed papers were mostly the Arduino UNO and Arduino Mega. The Arduino UNO is the most popular Arduino board; it is powered by the Atmega328 processor and is compatible with most development board shields. The Arduino Mega is powered by the ATmega2560 processor and has more I/O pins and larger memory space than the UNO. However, this can be disadvantageous, as it is more expensive and larger in size. In some studies, the Arduino Nano was used. The Arduino Nano has the same performance as the UNO, but its smaller size makes it suitable for tight environments. However, as compared to the UNO, the disadvantage is that it cannot be combined with Arduino shields [31]. The type of Arduino board discussed in each article is summarized in Table 2.
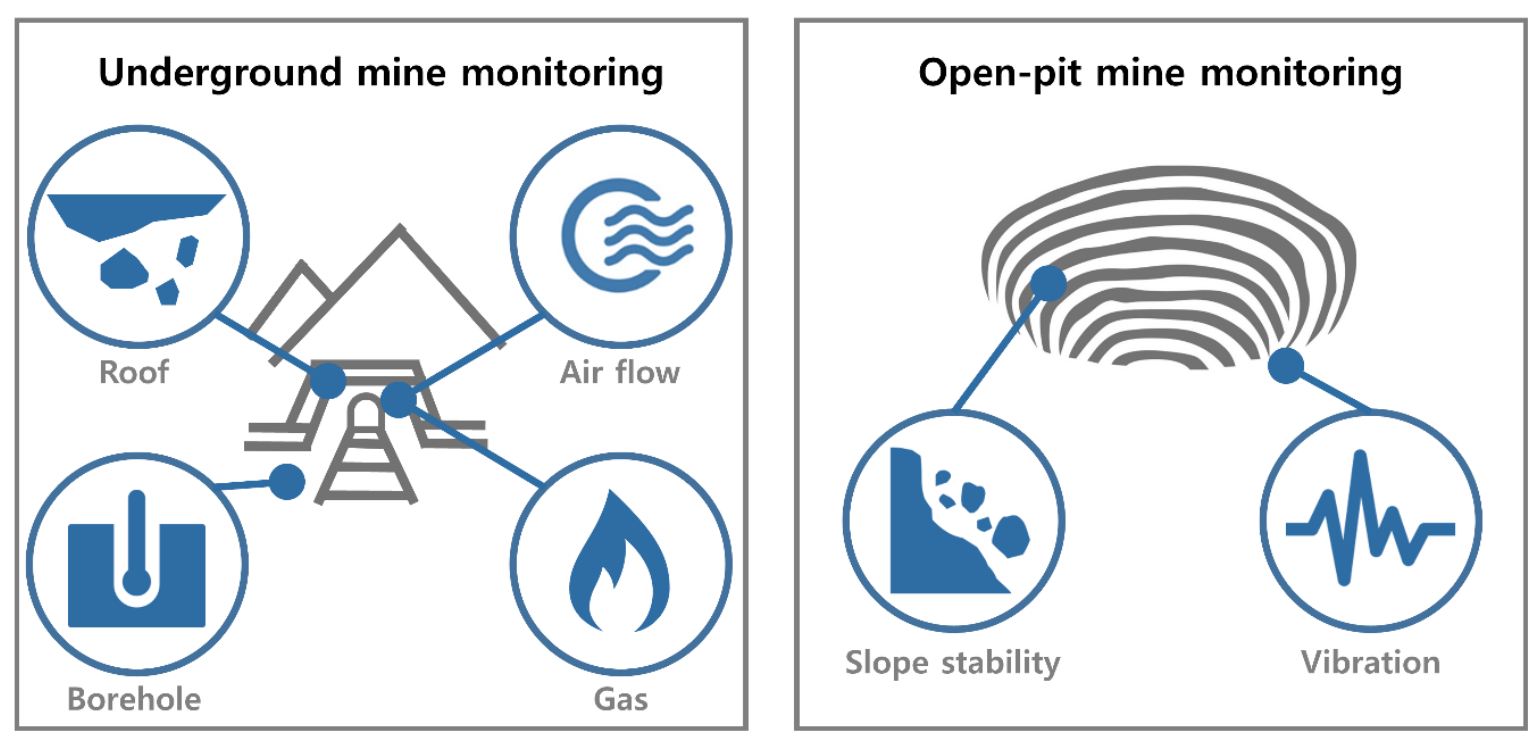

Figure 2. Typical applications of an Arduino-based field monitoring system.

Arduino-compatible sensors can be used (depending on the type of gas) to evaluate the level of gas, which is directly related to worker safety in underground mines. In open-pit mines, geotechnical problems may be more critical than air quality problems, and some studies based on Arduino have been conducted to acquire geotechnical data. As it is difficult to communicate in an underground mine, it is necessary to configure wireless sensor networks (WSNs) to transmit information to the outside. Sensor nodes with computing power can configure a WSN to send data to a main location or sink, where the data can be observed and analyzed [32]. Many of the reviewed studies built WSNs with Arduino-based sensor nodes. Even in open-pit mines, wireless communication instead of physical cables can be useful, in that it is cost-effective and has no physical constraints. For data communication, wireless technologies such as Bluetooth, $\mathrm{Wi}-\mathrm{Fi}$, and ZigBee were used. Table 2 summarizes the sensors and wireless communication technologies used in the reviewed studies. Several sensors have been used in many studies to measure atmospheric and geological information. The main functions of these sensors are listed in Table 3.

Some studies are not only concerned with acquiring data, but also address taking additional measures, such as providing alarms using actuators. Table 2 summarizes the actuators used in each study. Most studies in field monitoring systems are directly or indirectly related to safety at the mining site. 
Table 2. Summary of Arduino applications for field monitoring systems.

\begin{tabular}{|c|c|c|c|c|c|c|c|}
\hline Reference & Mine type & $\begin{array}{c}\text { Purpose of Field } \\
\text { Monitoring System }\end{array}$ & Microcontroller & Sensor & Communication & $\begin{array}{c}\text { Actuator or } \\
\text { Other Modules }\end{array}$ & Additional Analysis \\
\hline Naidu et al. [33] & underground & air quality monitoring & Arduino UNO & gas (MQ2), temperature (LM35) & $\mathrm{Li}^{-\mathrm{Fi}}{ }^{1}$ & headphone & N/A \\
\hline $\begin{array}{l}\text { Anitha and } \\
\text { Seshagiri [34] }\end{array}$ & underground & air quality monitoring & Arduino UNO & $\begin{array}{l}\text { gas (MQ6), temperature (LM35), } \\
\text { fire sensor }\end{array}$ & ZigBee (Xbee) & buzzer & N/A \\
\hline Srivastava [35] & underground & air quality monitoring & Arduino UNO & $\begin{array}{c}\text { gas (MQ4, MQ7, MG811), } \\
\text { temperature and humidity (DHT11) }\end{array}$ & ZigBee (Xbee) & buzzer, $\mathrm{LCD}^{2}$ & N/A \\
\hline Kugan et al. [36] & underground & air quality monitoring & Arduino Mega & $\begin{array}{l}\text { gas (MID04), temperature (LM35), } \\
\text { pressure, heart beat sensor }\end{array}$ & GSM $^{3}$ (SIM800) & buzzer, LED ${ }^{4}$ & N/A \\
\hline Bhagat [37] & underground & air quality monitoring & Arduino UNO & $\begin{array}{c}\text { gas (MQ4), temperature and } \\
\text { humidity (DHT11) }\end{array}$ & ZigBee (Xbee) & N/A & N/A \\
\hline Ünsal et al. [38] & underground & air quality monitoring & Arduino UNO & $\begin{array}{c}\text { gas (MQ4, MQ7, MQ9), temperature } \\
\text { and humidity (DHT22) }\end{array}$ & $\mathrm{RF}^{5}(\mathrm{nRF} 24 \mathrm{~L} 01)$ & N/A & battery life analysis \\
\hline Nath et al. [39] & underground & air quality monitoring & Node MCU & $\begin{array}{c}\text { gas }(\mathrm{Au}-\mathrm{ZnO}, \mathrm{Au}-\mathrm{WO} 3 \\
\mathrm{Au}-\mathrm{TiO} 2, \mathrm{Au}-\mathrm{CuO})\end{array}$ & Wi-Fi (ESP8266) & alarm system & N/A \\
\hline Shah et al. [40] & polluted area & air quality monitoring & Arduino Mega & $\begin{array}{c}\text { gas (MQ2, MQ4, MQ7, MQ135), } \\
\text { temperature and humidity } \\
\text { (DHT11, DHT22) }\end{array}$ & Wi-Fi (ESP8266) & LCD & N/A \\
\hline $\begin{array}{l}\text { Rajalakshmi and } \\
\text { Vidhya [41] }\end{array}$ & polluted area & air quality monitoring & Arduino UNO & $\begin{array}{c}\text { gas (MQ2, MQ7, MQ8, MQ9), } \\
\text { temperature (LM35) }\end{array}$ & GSM (SIM900A) & N/A & $\mathrm{N} / \mathrm{A}$ \\
\hline $\begin{array}{c}\text { Sudila and } \\
\text { Elvitigala [42] }\end{array}$ & underground & air quality monitoring & $\begin{array}{l}\text { Arduino UNO, } \\
\text { Mega }\end{array}$ & gas (MQ2, MQ7) & GSM (SIM800) & $\begin{array}{l}\text { Buzzer, LCD, } \\
\text { RTC }^{6}\end{array}$ & regression analysis \\
\hline Jo and Khan [28] & underground & air quality monitoring & Arduino Mega & $\begin{array}{c}\text { gas (MQ4, MQ9, MQ135), } \\
\text { temperature and humidity (DHT11) }\end{array}$ & BLE $^{7}$ (BLE shield) & N/A & k-means clustering \\
\hline Durán et al. [43] & underground & air quality monitoring & Arduino UNO & $\begin{array}{c}\text { gas (MQ2, MQ3, MQ6, MQ7, } \\
\text { MQ8, MQ9), }\end{array}$ & ZigBee (Xbee) & $\begin{array}{l}\text { Vacuum pump } \\
\quad \text { (T2-03) }\end{array}$ & $\mathrm{PCA}^{8}, \mathrm{LDA}^{9}$ \\
\hline Jo and Khan [44] & underground & air quality monitoring & Arduino UNO & $\begin{array}{l}\text { gas (MQ4, MQ9, MG811, } \\
\text { MQ136, MiCs2714) }\end{array}$ & ZigBee (Xbee) & N/A & PCA, ANN ${ }^{10}$ \\
\hline Mondal et al. [45] & underground & air quality monitoring & Arduino Due & gas $(\mathrm{ZnO}, \mathrm{ZnO}-\mathrm{SnO} 2)$ & $\mathrm{N} / \mathrm{A}$ & N/A & $\begin{array}{l}\text { gas classification } \\
\text { (ANN) }\end{array}$ \\
\hline $\begin{array}{l}\text { Rodriguez-Diaz } \\
\text { et al. [46] }\end{array}$ & underground & air flow monitoring & Arduino Mega & $\begin{array}{l}\text { air flow (hot wire sensor, mass flow } \\
\text { sensor, orifice plate sensor) }\end{array}$ & N/A & centrifugal fan & $\begin{array}{l}\text { ventilation network } \\
\text { modeling }\end{array}$ \\
\hline Adjiski et al. [47] & underground & air quality monitoring & Arduino Nano & gas (MQ7) & Bluetooth (HC05) & $\mathrm{N} / \mathrm{A}$ & $\mathrm{COHb}^{11}$ calculation \\
\hline Adjiski et al. [48] & underground & air quality monitoring & Arduino Nano & gas (MQ7) & Bluetooth (HC05) & N/A & $\begin{array}{l}\mathrm{COHb} \text { calculation, fire } \\
\text { scenario simulation }\end{array}$ \\
\hline Pop et al. [49] & underground & air quality monitoring & Arduino UNO & gas (MQ2) & ZigBee (Xbee) & N/A & $\begin{array}{l}\text { probabilistic strategy } \\
\text { for potentially } \\
\text { explosive area }\end{array}$ \\
\hline
\end{tabular}


Table 2. Cont.

\begin{tabular}{|c|c|c|c|c|c|c|c|}
\hline Reference & Mine type & $\begin{array}{c}\text { Purpose of Field } \\
\text { Monitoring System }\end{array}$ & Microcontroller & Sensor & Communication & $\begin{array}{c}\text { Actuator or } \\
\text { Other Modules }\end{array}$ & Additional Analysis \\
\hline Jayanthu et al. [50] & open-pit & slope monitoring & Arduino Mega & time domain reflectometry (TDR) & ZigBee (Xbee) & $\mathrm{N} / \mathrm{A}$ & N/A \\
\hline $\begin{array}{l}\text { Karthik and } \\
\text { Jayanthu [51] }\end{array}$ & open-pit & slope monitoring & Arduino Mega & time domain reflectometry (TDR) & ZigBee (Xbee) & N/A & $\begin{array}{c}\text { Zigbee module range } \\
\text { test }\end{array}$ \\
\hline $\begin{array}{c}\text { Jayanthu and } \\
\text { Karthik [52] }\end{array}$ & open-pit & slope monitoring & Arduino Mega & time domain reflectometry (TDR) & ZigBee (Xbee) & N/A & $\begin{array}{c}\text { Zigbee module range } \\
\text { test }\end{array}$ \\
\hline Jayanthu et al. [53] & open-pit & slope monitoring & Arduino UNO & accelerometer (ADXL345) & GSM (SIM800) & $\mathrm{N} / \mathrm{A}$ & N/A \\
\hline $\begin{array}{c}\text { Prashanth and } \\
\text { Nimaje [54] }\end{array}$ & open-pit & vibration monitoring & Arduino UNO & accelerometer (ADXL335) & GSM (SIM800) & $\mathrm{N} / \mathrm{A}$ & N/A \\
\hline Tiwari et al. [55] & underground & borehole monitoring & Arduino UNO & ultrasonic sensor & $\mathrm{N} / \mathrm{A}$ & N/A & N/A \\
\hline Alzahrani [56] & underground & roof monitoring & Arduino UNO & LiDAR $^{12}$ sensor (M16) & ZigBee (Xbee) & $\begin{array}{l}\text { linear actuator } \\
\text { (EZC4-05M), } \\
\text { motor controller }\end{array}$ & $\begin{array}{l}\text { statistical analysis for } \\
\text { removing anomalies }\end{array}$ \\
\hline
\end{tabular}

${ }^{1}$ Li-Fi: light fidelity; ${ }^{2}$ LCD: case based reasoning; ${ }^{3}$ GSM: global system for mobile communication; ${ }^{4}$ LED: light-emitting diode; ${ }^{5}$ RF: radio frequency; ${ }^{6}$ RTC: real-time clock; ${ }^{7}$ BLE: bluetooth low energy; ${ }^{8}$ PCA: principal component analysis; ${ }^{9}$ LDA: linear discriminant analysis; ${ }^{10}$ ANN: artificial neural network; ${ }^{11} \mathrm{COHb}$ : carboxyhemoglobin; ${ }^{12}$ LiDAR: light detection and ranging. 
Table 3. Sensors used in the reviewed articles for field monitoring.

\begin{tabular}{|c|c|c|}
\hline Sensor Name & Sensor Type & Detect \\
\hline MQ2 & Gas sensor & Methane, butane, $\mathrm{LPG}^{1}$, smoke \\
\hline MQ3 & Gas sensor & Alcohol, ethanol, smoke \\
\hline MQ4 & Gas sensor & Methane, natural gas \\
\hline MQ6 & Gas sensor & LPG, butane gas \\
\hline MQ7 & Gas sensor & Carbon monoxide \\
\hline MQ8 & Gas sensor & Hydrogen gas \\
\hline MQ9 & Gas sensor & Carbon monoxide, flammable gases. \\
\hline MQ135 & Gas sensor & Air quality (benzene, alcohol, smoke) \\
\hline MQ136 & Gas sensor & Hydrogen sulfide gas \\
\hline MG811 & Gas sensor & Carbon dioxide \\
\hline MiCs2714 & Gas sensor & Nitrogen dioxide \\
\hline DHT11 & Temperature and Humidity sensor & $\begin{array}{l}\text { Temperature range: } 0-50{ }^{\circ} \mathrm{C}\left( \pm 2{ }^{\circ} \mathrm{C}\right) \\
\text { Humidity range: } 20-80 \% \mathrm{RH}\left( \pm 5 \% \mathrm{RH}^{2}\right)\end{array}$ \\
\hline DHT22 & Temperature and Humidity sensor & $\begin{array}{l}\text { Temperature range: }-40-80^{\circ} \mathrm{C}\left( \pm 0.5^{\circ} \mathrm{C}\right) \\
\text { Humidity range: } 0-100 \% \mathrm{RH}( \pm 2 \% \mathrm{RH})\end{array}$ \\
\hline LM35 & Temperature sensor & Temperature range: $-55^{\circ} \mathrm{C}$ to $150^{\circ} \mathrm{C}\left( \pm 0.5^{\circ} \mathrm{C}\right)$ \\
\hline ADXL335 & Accelerometer & 3-axis sensing ( \pm 3 g measurement range) \\
\hline ADXL345 & Accelerometer & 3 -axis sensing ( $\pm 16 \mathrm{~g}$ measurement range) \\
\hline
\end{tabular}

\subsection{Atmospheric Monitoring}

Naidu et al. [33] developed a system for measuring hazardous gases and temperatures in underground mines and providing warning messages using light fidelity ( $\mathrm{Li}-\mathrm{Fi})$ technology. Li-Fi uses light from the infrared to the near-ultraviolet spectrum. An LM35 sensor was used to measure the temperature in the underground environment, and an MQ2 sensor was used to detect combustible gases such as liquefied petroleum gas (LPG), propane, hydrogen $\left(\mathrm{H}_{2}\right)$, and methane $\left(\mathrm{CH}_{4}\right)$. A system using the Arduino UNO as a microcontroller was built in each of the mining and control rooms. The system in the mining area transmitted information to the control room through $\mathrm{Li}-\mathrm{Fi}$ after measuring the gas and temperature, and the control room served to collect information from multiple mining areas. As Li-Fi was used as the communication technology, this study had the advantage of being secure; there was no interference with radio frequencies. However, there were limitations; only laboratory tests were conducted, without application to actual mines.

Anitha and Seshagiri [34] established a monitoring system based on ZigBee communication for safety in coal mines. The temperature was measured using the LM35 sensor, and the gas was detected using an MQ6 sensor. The MQ6 sensor is used to detect gases such as propane, butane, LPG, and natural gas. In addition, a fire sensor that could detect fires within $1 \mathrm{~m}$ was used to prevent fires. The measured value could be checked through a liquid crystal display (LCD), and an alarm could be triggered through a buzzer. The fire could be extinguished using a motor and fan, but the effectiveness of this approach was not verified, as it was not applied to an actual mine site. Using Arduino UNO as a microcontroller, it involved connecting sensors and actuators and building a ZigBee-based WSN. The monitoring system consisted of an underground section and ground section. The underground section acquired and transmitted information, and the ground section received information.

In a similar way, a real-time monitoring system for underground mines [35] was constructed using Arduino UNO and ZigBee modules. In this study, an MQ7 sensor for carbon monoxide (CO) detection, an MQ4 sensor for $\mathrm{CH}_{4}$ detection, an MG811 sensor for carbon dioxide $\left(\mathrm{CO}_{2}\right)$ detection, 
and a DHT11 sensor for temperature and humidity were used. When a value above a threshold was measured, it was possible to provide an alert through a buzzer and LCD. The measured value was transmitted to a personal computer through the ZigBee module. However, this study was again conducted only in the laboratory. Although the types of sensors and communication modules are different, similar studies [36,37] in the mining industry are gradually increasing. In underground or abandoned mines, it is generally difficult to supply power through electric wires; thus, these wireless sensor-based systems need to be operated with batteries.

Ünsal et al. [38] analyzed the battery life when sensors such as MQ4, MQ7, MQ9, and DHT22 were connected to an Arduino UNO. In addition, they proposed a method for optimizing the battery life by performing experiments, so that the system could be operated for as long as possible. In general, similar types of sensors are used to measure hazardous gases in mines, but new sensors were proposed and verified by Nath et al. [39]. To detect hazardous gas more efficiently in mines, a nanogas-sensing device was proposed, based on a sol-gel method of depositing gold particles on $\mathrm{ZnO}, \mathrm{WO}_{3}, \mathrm{TiO}_{2}$, and $\mathrm{CuO}$ thin films. As a result of experiments on $\mathrm{CH}_{4}, \mathrm{H}_{2}$, and $\mathrm{N}_{2}$ gases, it was reported that the selectivity and sensitivity were improved as compared to existing sensors. The measured values were acquired wirelessly through the Wi-Fi module of the Node MCU (ESP8266), as programmed via the Arduino IDE. If applied to actual mines in the future, the results of this study will improve the accuracy of gas detection in mines. Most air quality monitoring studies have been conducted inside underground mines, but some studies have been conducted to measure air quality outside a mine.

Shah et al. [40] built a monitoring system using the Arduino Mega and a Wi-Fi module (ESP8266) to measure sewer gas discharged through a pipeline. DHT11 and DHT22 sensors were used to measure the temperature and humidity, and gases such as $\mathrm{LPG}, \mathrm{CH}_{4}, \mathrm{CO}_{2}$, and $\mathrm{CO}$ were measured using MQ2, MQ4, MQ135, and MQ7 sensors, respectively. The measurement results are displayed on an LCD and transmitted to the IBM Bluemix, and execution of IBM's Open Cloud Architecture via Wi-Fi. Rajalakshmi and Vidhya [41] developed a monitoring system for gases emitted from an environment polluted by mining. MQ2 sensors (for flammable gas), MQ7 sensors (for CO), MQ8 sensors (for hydrogen $\left(\mathrm{H}_{2}\right)$ ), and MQ9 sensors (for $\mathrm{LPG}$ ) were connected to an Arduino UNO, and LM35 sensors were used for temperature measurement. When a measured value reached a dangerous level, an SMS message was transmitted to a mobile phone through a global system for mobile communication (GSM) module. In practice, the main technology applied to gas monitoring outside a mine is not much different from that used in studies in underground mines. However, because communication outside the mine is simpler, it is possible to directly connect to a server, or to send a message from the monitoring system without the construction of a WSN.

The studies discussed above considered approaches that transmit and monitor data in real time. However, it is difficult for mineworkers to respond immediately to dangerous situations based simply on monitoring the current conditions. Therefore, to respond immediately to an emergency, it is necessary to predict and prepare for situations. Some studies are designed to predict or respond to dangerous situations in advance through additional analysis based on monitoring data. Sudila and Elvitigala [42] connected MQ2 and MQ7 gas sensors to an Arduino UNO and installed them as local sensor nodes at different levels of a mine. Each sensor node was connected to an Arduino Mega-based main controlling system and transmitted data to the internet using a GSM module. When a gas sensor value exceeded a threshold, an alarm was triggered through a buzzer, and the gas level was predicted by applying a regression algorithm. The prediction results provided feedback to the system, including gas level fluctuations and predicted the gas inhalations of workers. Some studies have detected anomalies from the measurement of dangerous gases.

Jo and Khan [28] established an integrated system capable of gas monitoring, miner tracking, and cloud computing for the Hassan Kishore coal mine in Punjab, Pakistan (Figure 3). DTH11, MQ135, MQ9, and MQ4 sensors were connected to an Arduino Mega with a BLE shield to measure the temperature and humidity, $\mathrm{CO}_{2}, \mathrm{CO}$, and $\mathrm{CH}_{4}$, respectively. Some stationary nodes for collecting data were connected to router nodes, and the collected data were transmitted to a base station capable 
of a global internet connection (Figure 4). In addition, by using a mobile node connected through BLE, a miner could send an emergency signal, and the location could be tracked. In this study, a "mine warning index" (MWI) was proposed for comprehensively analyzing the measured values, and abnormal events were detected using K-means clustering. As each stationary node had its own built-in algorithm, event detection was possible even if the node was disconnected from the network.

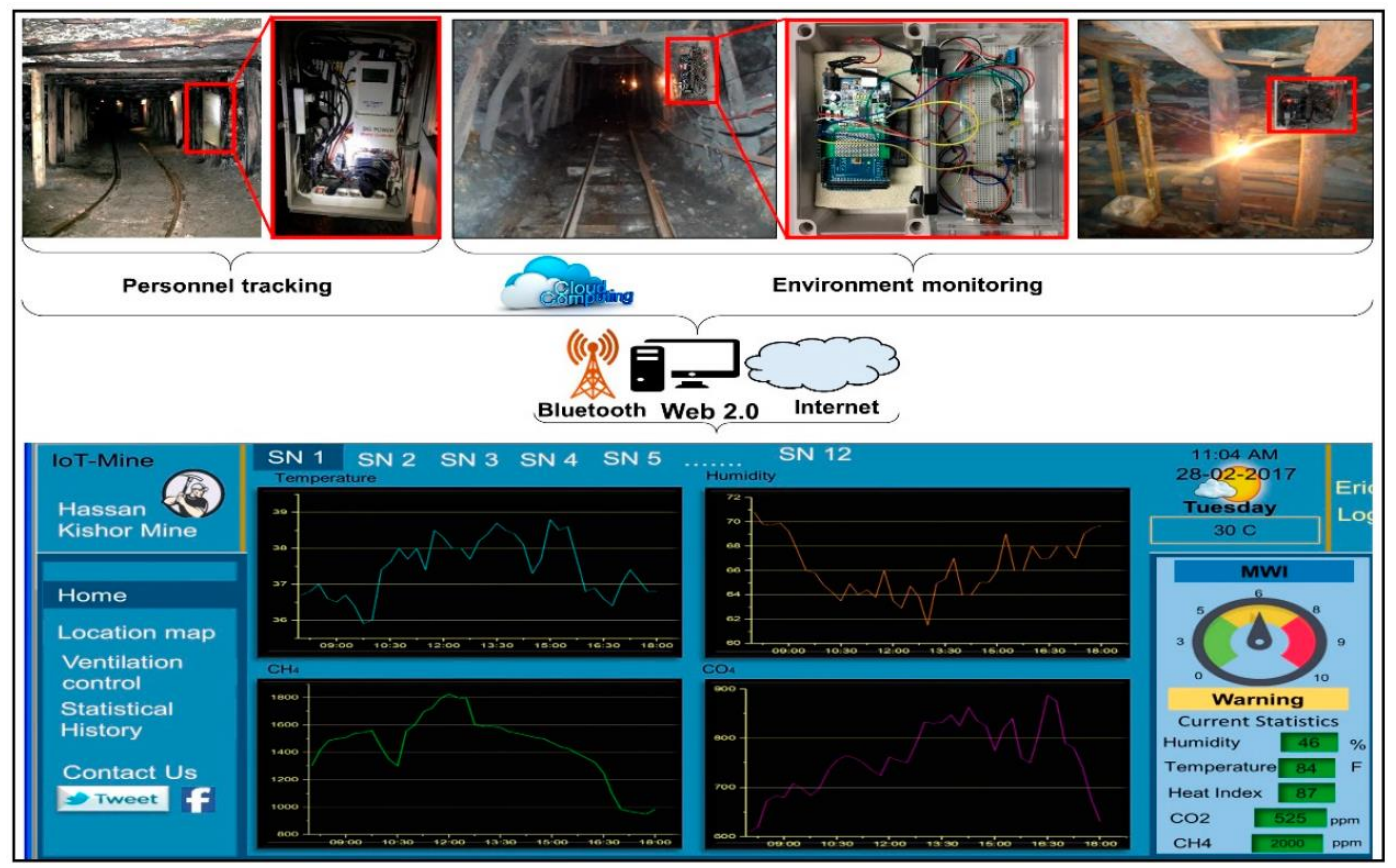

Figure 3. A brief description of an early warning Internet of Things (IoT)-based system in mines [29].

Durán et al. [43] constructed an electronic nose by arranging various gas detection sensors (MQ2, 3, 6-9) into one chamber. The sensors were connected to an Arduino UNO. The electronic nose inhaled and exhaled the gas using two vacuum pumps. After the measured values were transmitted through ZigBee communication, the types of gas were classified using principal component analysis (PCA) and linear discriminant analysis. As a result of classifying butane, $\mathrm{CH}_{4}, \mathrm{CO}$, and mixed gases using the measured values, the system demonstrated a classification accuracy of approximately $97 \%$. As even one type of sensor can be sensitive to multiple gases, this analysis was expected to help in identifying harmful gases. Although the study was conducted for application in coal mines, it was only tested in the laboratory.

Jo and Khan [44] also used PCA to identify the most influential gases among $\mathrm{CH}_{4}, \mathrm{CO}$, sulfur dioxide $\left(\mathrm{SO}_{2}\right)$, and hydrogen sulfide $\left(\mathrm{H}_{2} \mathrm{~S}\right)$ in an actual underground coal mine (Shangwan Coal Mine, Erdos, China). The PCA results were used as variables of an artificial neural network (ANN), to predict future air pollution. To obtain the data necessary for PCA analysis, some sensors (DHT11, MQ4, MQ9, MG811, MQ136, and MiCs2714) were connected to the Arduino UNO (Figure 5), and the data were transferred to the Azure machine learning (AML) platform using a ZigBee communication module (Figure 6). Although Arduino does not directly perform PCA or ANN analysis, an IoT system based on Arduino can interact with an AML platform in real time. To detect flammable and toxic gases, such as $\mathrm{H}_{2}, \mathrm{CH}_{4}$, and $\mathrm{CO}$, Mondal et al. [45] used an ANN-based pattern recognition technique. An array of $\mathrm{ZnO}$-based sensors was fabricated in the laboratory and was used to measure gas concentrations. A feed-forward back-propagation neural network was used for the classification of the gases at critical concentrations. The optimized ANN was implemented in an Arduino Due based on the Atmel (SAM3X8E ARM Cortex-M3 CPU) 32-bit ARM core microcontroller. The results of this experiment were verified under laboratory conditions. These studies monitored air quality and produced new information through additional analysis of the data. These results can help prepare for 
risks, by providing more useful information to mineworkers. However, most of them only interpret information regarding air quality and do not provide information on how to manage possible dangers.

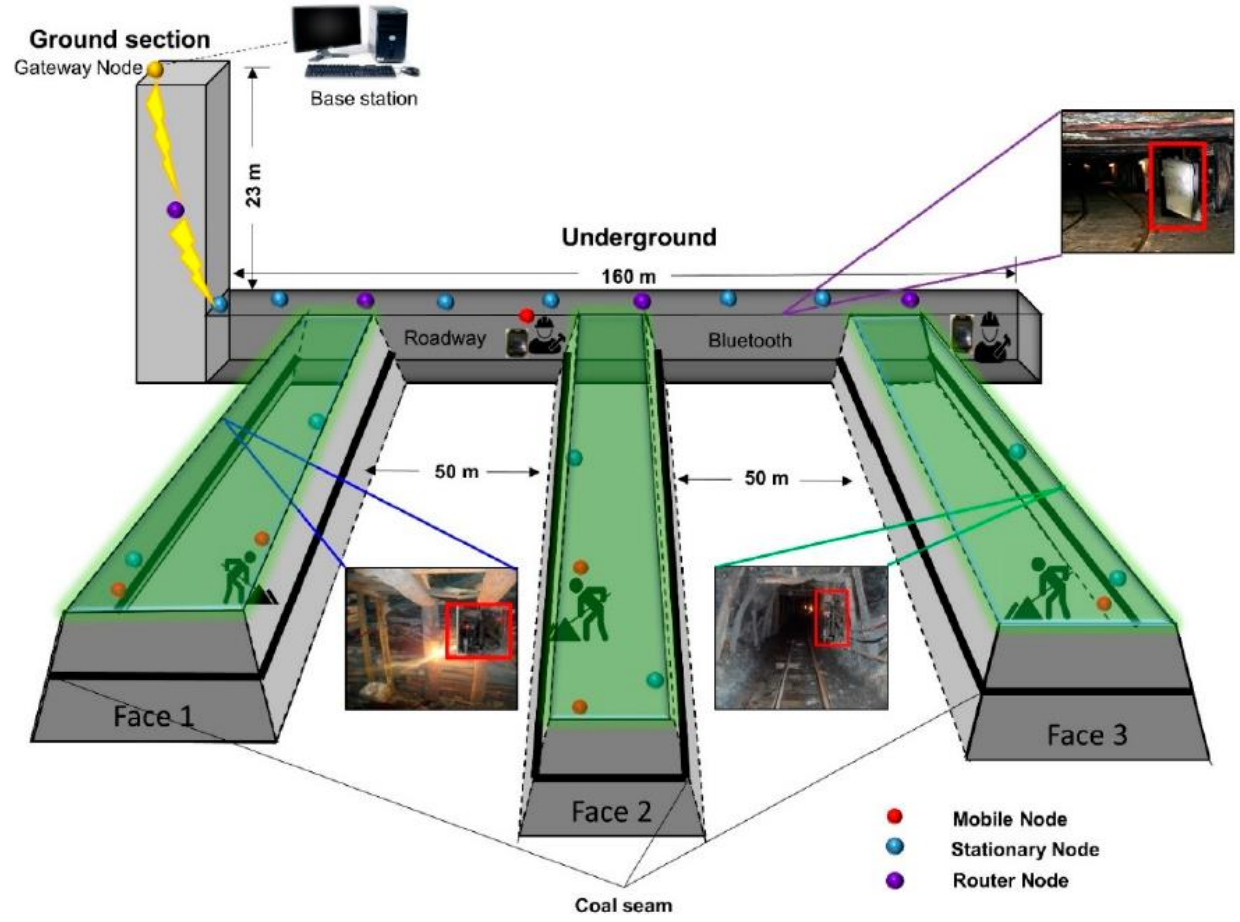

Figure 4. Layout of stationary nodes (SNs), router nodes (RNs), gateway, and moving anchor (MN) in the Hassan Kishore coal mine for enhanced safety [28].
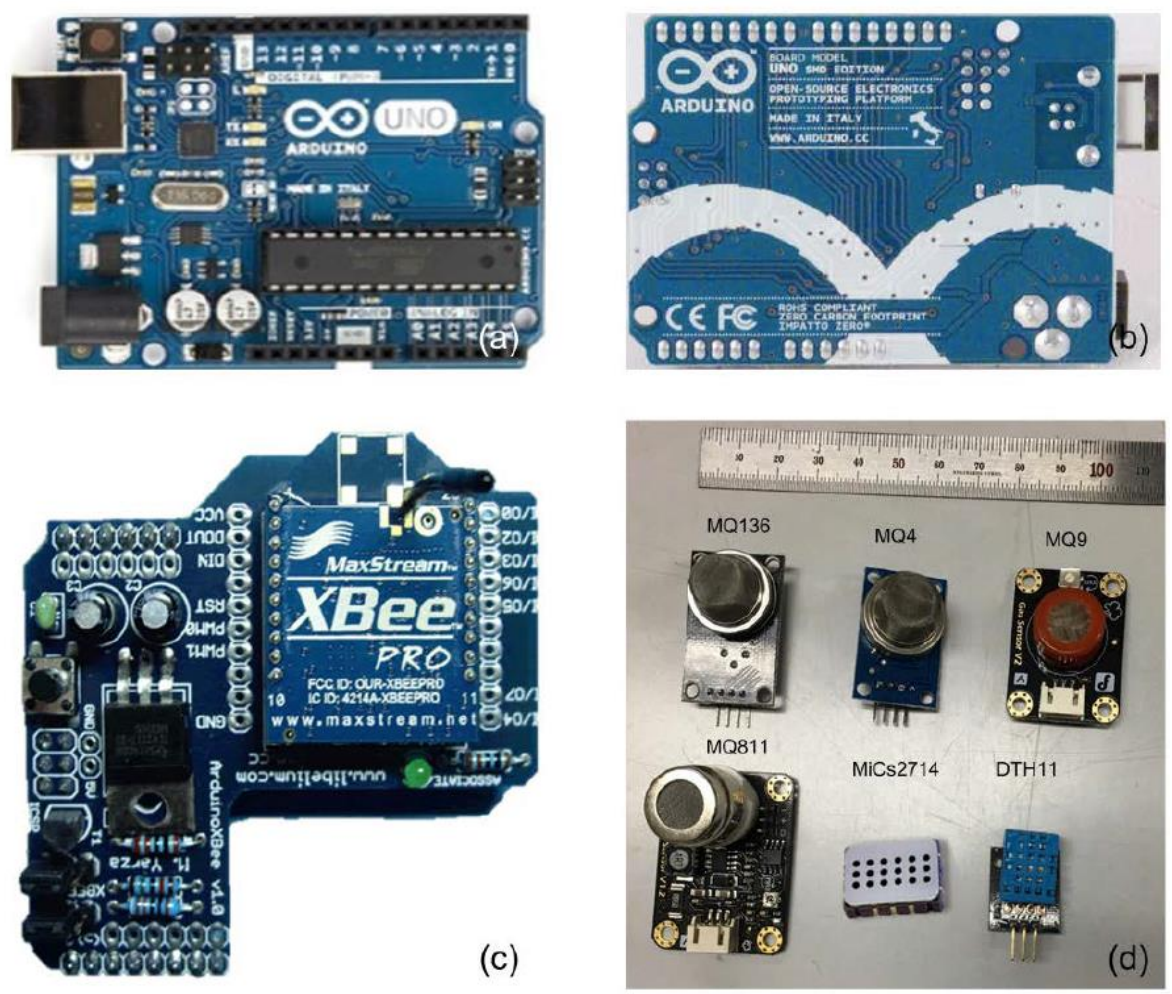

Figure 5. (a) Front pictorial aspect of Arduino UNO, (b) back-side pictorial aspect of Arduino UNO, (c) $2.4 \mathrm{GHz}$ ZigBee shield for Arduino, and (d) visual aspect of MQ4, MQ9, MG811, MiCs2714, and DHT11 [44]. 
Several studies have modeled situations for ventilation or escape from underground mines using atmospheric data. These results can help miners manage serious problems. To analyze the ventilation networks in small-scale underground mines, Rodriguez-Diaz et al. [46] used an Arduino Mega board with various types of sensors. The network, scaled down to a 1:500 scale, was configured using pipes; centrifugal fans were used as actuators to drive the air flow. A hot wire sensor, mass flow sensor, and orifice plate sensor were used to measure the air flow. As a result, it was possible to effectively observe the air flow and control the ventilation system; however, this study has not been applied to various other gases. In addition, it is necessary to apply the study to real mine sites.

Adjiski et al. [47] simulated $\mathrm{CO}$ inhalation as a carboxyhemoglobin $(\mathrm{COHb})$ level (\%) according to the escape route when a fire occurred in an underground mine. Arduino Nano 3.0 and MQ7 sensors were used to detect $\mathrm{CO}$ and to transmit the measured values to a mobile phone through a Bluetooth module. The $\mathrm{COHb}$ level was predicted from an application installed on the mobile phone, thereby suggesting a suitable escape route. Adjiski et al. [48] further developed this study, in conjunction with other software. An Arduino board was used for monitoring and transmitting data. Thus, the role of Arduino was similar to that of the previous study, but a specific situation was simulated in three dimensions using VentFIRE (a part of the ventilation software Ventsim (Howden, Australia)). In addition, a scaled-down model was constructed for testing the monitoring and alarm system using Arduino. As a result, the mobile application connected with the Arduino suggested a proper location for a self-rescuer device according to the data and could provide a warning when a dangerous situation occurred. To evaluate potentially explosive areas in underground coal mines, Pop et al. [49] considered three conditions potentially affecting the explosion (i.e., flammable material, sufficient oxygen, and energy supply). An MQ2 sensor was connected to an Arduino UNO to measure $\mathrm{CH}_{4}$, and a WSN was configured via ZigBee. A probabilistic strategy was presented by analyzing the measured data and other conditions to simulate a potential area.

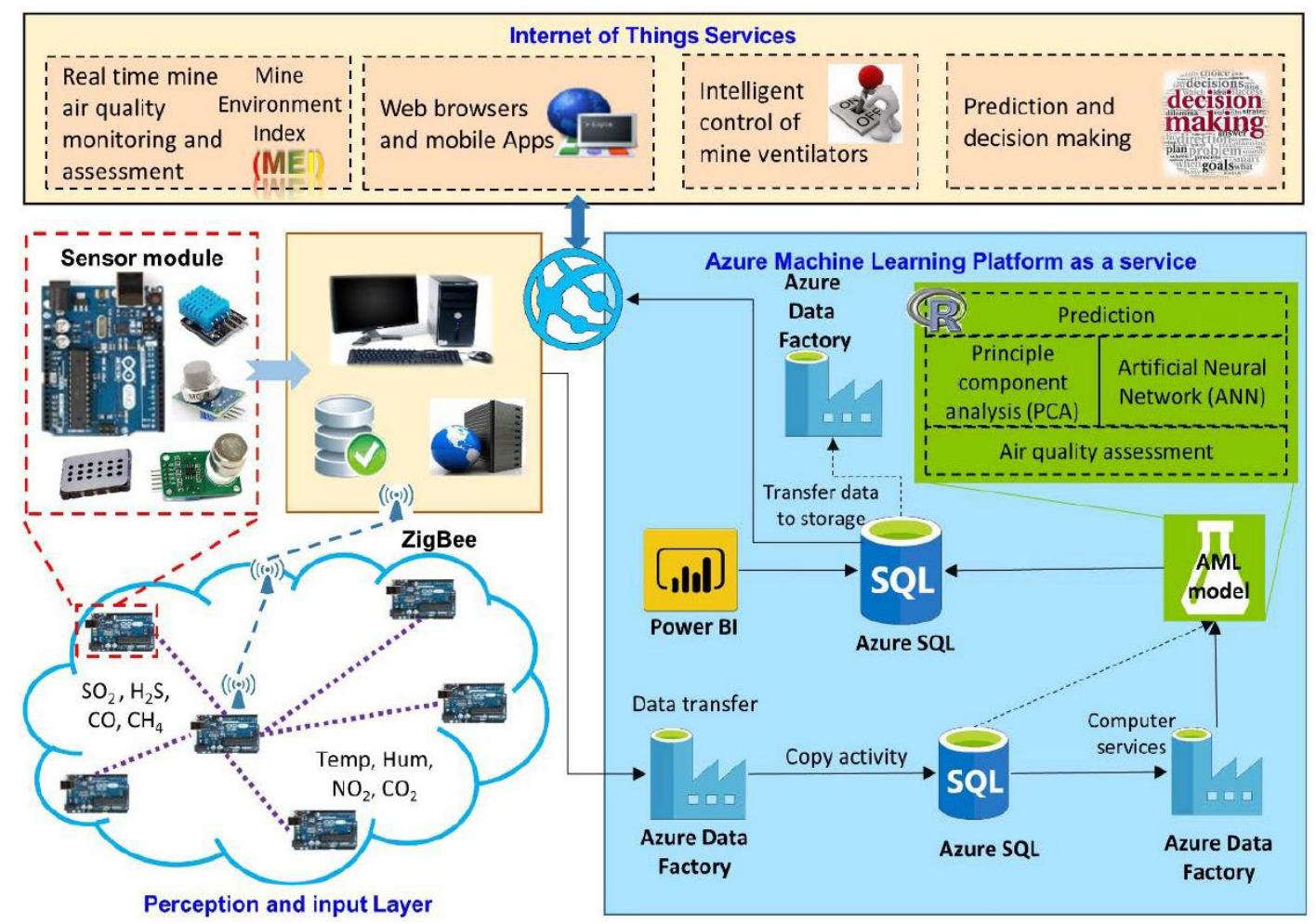

Figure 6. System architecture comprising Arduino used as a microcontroller for air quality monitoring in. mines, based on Azure machine learning (AML), for air quality prediction [44]. 


\subsection{Geotechnical Monitoring}

To prevent disasters in the mining industry caused by ground movements, applications in electronics, instrumentation, and computer science are very important [57]. To precisely measure ground movements, expensive instruments have generally been required. However, relatively low-cost auxiliary sensors combined with Arduino are becoming more useful. In addition, there have been some cases where communication using Arduino has been used to transmit data obtained from precise instruments and other sensors.

Slope stability is a major geological problem in open-pit mines. Several studies have reported on Arduino applications for ensuring the slope stability of open-pit mines. Jayanthu et al. [50] monitored the ground deformation of a slope of the Dongri Buzurg open-pit mine (India) using time domain reflectometry (TDR). TDR, a cable-based radar approach, measures a change in cable impedance when a cable is deformed by ground movements. In the study, the measured value was transmitted to an office in real time through an Arduino Mega combined with a ZigBee module (Xbee Pro). In addition, to select the appropriate installation benches for the monitoring instrument, the results of the ZigBee module range test and numerical modeling were considered [51].

A similar study using products with the same specifications was conducted at the Panna Diamond Mine (National Mineral Development Corporation Ltd., India) [52]. In this study, various conditions and communication ranges were tested, so that the developed system could be applied to typical mines. Jayanthu et al. [53] monitored the angle of a surface slope in the Dongri Buzurg open-pit mine using an Arduino UNO and accelerometers (ADXL345); this approach was cheaper than TDR. By installing multiple accelerometers and constructing a dense network, it was possible to detect rock movements that were difficult for certain precise instruments to detect. The measured values were transmitted to mobile or related platforms using a GSM module (SIM800). In the mining industry, slope stability is closely related to blasting. The ground vibration induced by blasting can cause severe damage to the surrounding structures and slopes.

Prashanth and Nimaje [54] measured peak particle velocity (PPV) by connecting an accelerometer (ADXL335) with an Arduino UNO. Compared to existing instruments connected by cables, which are expensive and cannot transmit information in real time, the proposed system was able to monitor PPV using the GSM module cost-effectively. Monitoring was conducted for $11 \mathrm{~d}$ at a mine in India. As a result, it was observed that as the distance from the blast face increased, the PPV value tended to decrease.

Research on geotechnical monitoring has yet to focus on open-pit mines. However, there have been some articles on the use of Arduino to understand the geological states in underground mines. In particular, roof-falls in underground mines can be a fatal danger to mineworkers; Arduino is being used in attempts to prevent this. Tiwari et al. [55] developed a wireless borehole extensometer using an acoustic wave propagation technique employing ultrasonic sensors, an Arduino UNO, and ZigBee modules. The ultrasonic sensors were connected to the Arduino and detected changes in the borehole by calculating the distance between the device and stratum. However, as this experiment was only tested on polyvinyl chloride pipes, field validation is required for practical use.

Alzahrani [56] developed an integrated system for detecting roof movements and providing warning notifications in underground mines. To test whether an inexpensive Light detection and ranging (LiDAR) sensor (M16 scanner) could detect ground movements, a rock displacement simulator controllable at a submillimeter resolution was developed. An electromechanical linear actuator (EZC4-05M, Oriental Motor USA Corporation) was connected to an Arduino UNO using a stepper motor controller. The measured distance was checked through an LCD, and remote control and data transmission was possible using the ZigBee module. As a result of the experiment, anomalies were included in the measured values, but they could be removed through statistical analysis. As a result, the M16 scanner could detect a simulated target plate profile with a precision between $0.1 \mathrm{~mm}$ and $3 \mathrm{~mm}$ per integration period. However, as this approach was only applied to a controlled experiment, it needs to be applied to a real mine. 


\section{Arduino in Wearable Systems}

\subsection{Overview}

Numerous accidents in underground mines (mainly coal mines) are caused by gas leakages, roof collapses, collisions with equipment, low oxygen concentrations, and other operating conditions. Thus, the mining industry has attempted to monitor positions of equipment, environmental quality, and ground vulnerability and to inform mine workers of this information to secure their safety and health. Toward this aim, in addition to field monitoring methods, various wearable devices and technologies for mine workers have recently been developed [58], particularly since Google Inc. launched head-mounted displays. The purpose of wearable device-based monitoring is similar to that of the aforementioned field monitoring. However, there are differences between the two systems, in that the measured value from the wearable system is more realistic to miners; an alarm can be activated immediately. A wearable safety management system in a mine environment can play a vital role in reducing the risk of accidents and in ensuring the safety and health of each miner. In this process, the Arduino has been applied in the mining industry as a controller for connecting sensing to an actuator, to develop wearable safety management systems such as a (smart or intelligent) helmet or belt.

Most wearable systems using Arduino in the mining industry consist of four parts: sensor, microcontroller (Arduino board), communication, and actuator elements (Figure 7).

- The sensor in wearable systems is closely related to the purpose of the system being developed. Various types of sensors are available on the market and are usually found on consumer wearable devices according to the intended application, such as environmental sensors, biosensors, and position tracking sensors. These sensors are embedded in wearable devices for observing or measuring real-time underground parameters, such as the gas concentration, temperature, humidity, atmospheric pressure, oxygen concentration (for air quality or air density monitoring purposes), piezoelectric characteristics (for device wearing status monitoring purposes), vibrations (for destructive event or collision detection purpose), human heart rates or pulse rates (for human biocharacteristics monitoring purposes), and positions of machines or workers (for location monitoring purposes).

- The microcontroller serves as a platform for receiving the data measured by sensors (sensor output) and for transmitting the data to monitoring stations through wireless communication or actuating a device (e.g., providing alarms such as a buzzer) under specific conditions (called threshold limit values or critical safety values) using the measured data, based on coding or programming an Arduino IDE or Python. Arduino is a widely used hardware with low power usage and an easy-to-use open-source software platform for most electronics projects. Thus, the Arduino Mega, Arduino Nano, and Arduino UNO board (models) are frequently used to control microcontroller boards in systems.

- A wireless communication function is necessary to transmit data to a remote office or web server at a control station, as a communication network is generally not installed in underground mines. To establish a wireless communication network, various wireless communication technologies for data transmission and receiving have been utilized in the reviewed published literature, such as ZigBee, Bluetooth, and radio frequency identification.

- An actuator refers to something (e.g., wearable device) that actuates something else (e.g., a sound, message, display, or vibration). In particular, an actuator is usually an electric device that causes a mechanical device to switch in some fashion. Various wearable devices have been developed, such as smartwatches, smart eyewear, fitness trackers, smart clothing, and wearable cameras, according to their functional properties and capabilities (Figure 8) [58]. However, most of the studies reviewed in this section employed a (smart) helmet as an actuator. The reason for this is as follows. All mine workers must wear a helmet during work hours for safety, regardless of the type of mine. Therefore, designing a system on a helmet has an advantage in that miners can always wear it, and it can reduce unnecessary costs, e.g., purchasing other wearable equipment. 


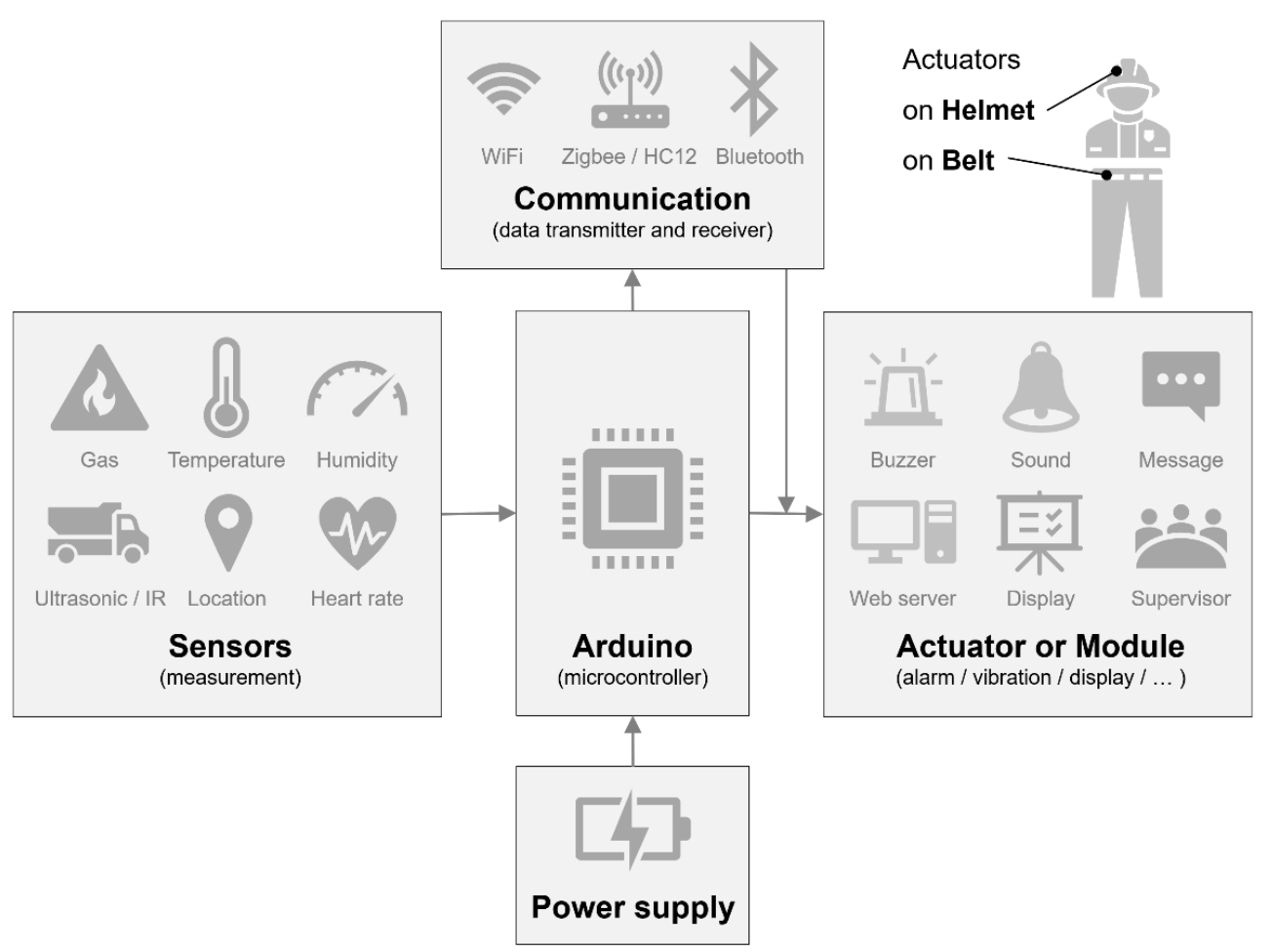

Figure 7. A descriptive diagram of an Arduino-based wearable safety management system.

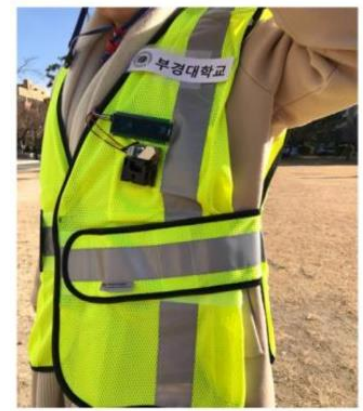

(a)

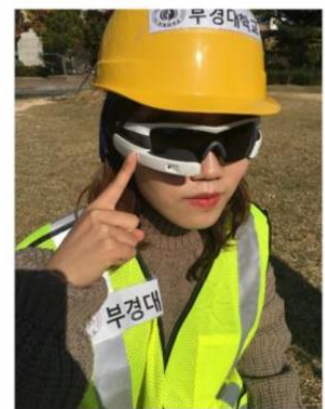

(b)

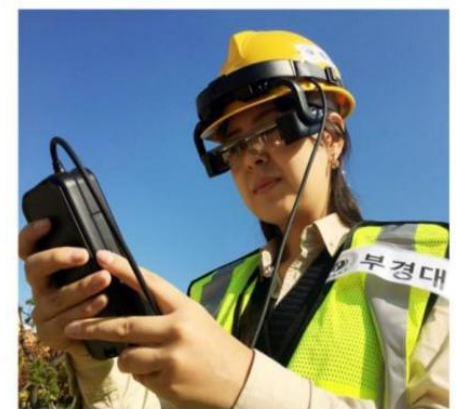

(c)

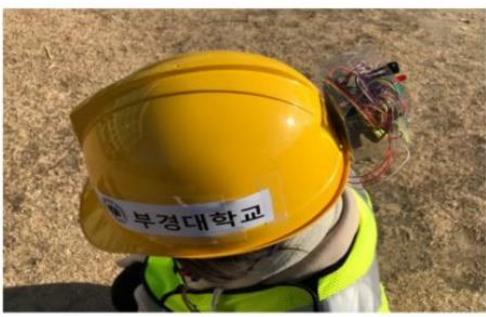

(d)

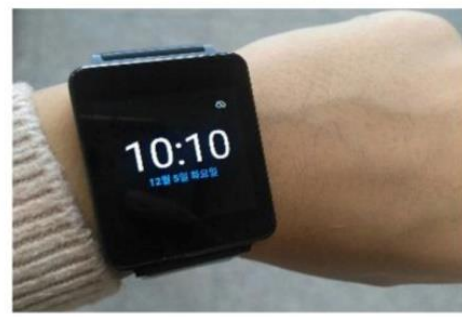

(e)

Figure 8. Examples of wearable systems used at mining sites: (a) sensor-equipped mine safety vast; (b) miner wearing Recon Jet Smart Eyewear; (c) miner using Epson Moverio BT-2200; (d) sensor-equipped safety helmet; (e) smartwatch [58].

In this wearable systems section, 13 papers were reviewed. Table 4 summarizes the Arduino applications for wearable safety management systems. All of the studies reviewed in this section were applied in underground mines (mostly underground coal mines, owing to gas leakage and ground instability). According to the sensing items of the wearable devices, the published literature on applications of Arduino in wearable systems in underground mines are divided into those regarding surrounding (in situ) information and those regarding human bioinformation. 
Table 4. Summary of Arduino applications for wearable systems.

\begin{tabular}{|c|c|c|c|c|c|c|}
\hline Reference & Type of Mine & $\begin{array}{c}\text { Purpose of } \\
\text { Wearable System }\end{array}$ & Microcontroller & Sensor & Communication & Actuator or Other Modules \\
\hline Majee [59] & Underground coal & $\begin{array}{l}\text { Air quality monitoring } \\
\text { Air density }\end{array}$ & $\begin{array}{l}\text { Arduino Nano } \\
\text { Arduino UNO }\end{array}$ & $\begin{array}{l}\text { Gas (MQ2, MQ4, and MQ135), air } \\
\text { density, temperature and humidity } \\
\text { (DHT11) }\end{array}$ & $\begin{array}{c}\text { ZigBee } \\
\text { Wi-Fi (ESP8266) }\end{array}$ & $\begin{array}{l}\text { Helmet with alarm system } \\
\text { Web server (at control station) }\end{array}$ \\
\hline Harshitha et al. [60] & Underground coal & Air quality monitoring & Arduino UNO & $\begin{array}{c}\text { Gas (MQ2), temperature (LM35), } \\
\text { humidity (DHT11), }\end{array}$ & ZigBee & $\begin{array}{c}\text { Helmet with buzzer } \\
\text { Web server (at control station) }\end{array}$ \\
\hline Roja and Srihari [61] & Underground coal & $\begin{array}{l}\text { Air quality monitoring } \\
\text { Helmet wearing status }\end{array}$ & Arduino UNO & $\begin{array}{l}\text { Gas (MQ6 and MQ7), Infrared (IR), } \\
\text { piezoelectric sensor }\end{array}$ & GSM (SIM800L) & $\begin{array}{c}\text { Helmet with buzzer } \\
\text { LCD (liquid crystal display) }\end{array}$ \\
\hline Bhuttoa et al. [62] & Underground coal & $\begin{array}{l}\text { Air quality monitoring } \\
\text { Collision detection }\end{array}$ & Arduino Nano & $\begin{array}{l}\text { Gas (MQ2), temperature and humidity } \\
\text { (DHT11), ultrasonic (HC-SR04) }\end{array}$ & N/A & Leather belt with buzzer, \\
\hline Noorin and Suma [63] & Underground & $\begin{array}{l}\text { Air quality monitoring } \\
\text { Collision detection } \\
\text { Helmet wearing status }\end{array}$ & Arduino Nano & $\begin{array}{l}\text { Gas (MQ4), temperature and humidity } \\
\text { (DHT11), vibration (SW420) }\end{array}$ & Wi-Fi & $\begin{array}{l}\text { Helmet with buzzer } \\
\text { and OLED } \\
\text { Alert to supervisor }\end{array}$ \\
\hline Priyadarsini et al. [64] & Underground coal & Heart rate monitoring & Arduino UNO & Heartbeat rate (ECG AD8232) & LabVIEW & Laptop (at control station) \\
\hline Dudwadkar et al. [65] & Underground coal & $\begin{array}{l}\text { Air quality monitoring } \\
\text { Heart rate monitoring }\end{array}$ & Arduino & $\begin{array}{c}\text { Gas (MQ135), temperature and } \\
\text { humidity (DHT11), heartbeat rate (IR } \\
\text { light reflection and refraction) }\end{array}$ & ZigBee (XBEE) & Laptop (at control station) \\
\hline Oliveira et al. [66] & Underground & $\begin{array}{c}\text { Navigation } \\
\text { Heart rate monitoring }\end{array}$ & Arduino Mega & Heartbeat rate & $\mathrm{N} / \mathrm{A}$ & Vibrotactile belt \\
\hline Alam et al. [29] & Underground coal & $\begin{array}{l}\text { Air quality monitoring } \\
\text { Heart rate monitoring }\end{array}$ & Arduino Mega & $\begin{array}{l}\text { Gas (MQ5), temperature and humidity } \\
\text { (HSM-20G), heartbeat rate (ear clip kit) }\end{array}$ & ZigBee & $\begin{array}{l}\text { Helmet with buzzer, } \\
\text { LCD (at control station) }\end{array}$ \\
\hline Dewarkar et al. [67] & Underground coal & $\begin{array}{l}\text { Air quality monitoring } \\
\text { Position monitoring } \\
\text { Pulse rate monitoring }\end{array}$ & Arduino Nano & $\begin{array}{c}\text { Gas (MQ7), temperature, pulses rate, } \\
\text { GPS }\end{array}$ & $\mathrm{RF}(\mathrm{HC} 12)$ & $\begin{array}{l}\text { Helmet with buzzer } \\
\text { Display screen }\end{array}$ \\
\hline Sanjay et al. [68] & Underground coal & $\begin{array}{l}\text { Air quality monitoring } \\
\text { Destructive event detection } \\
\text { Pulse rate monitoring }\end{array}$ & Arduino Nano & $\begin{array}{l}\text { Gas (MQ135), humidity, atmospheric } \\
\text { pressure and temperature (BMP180), } \\
\text { Infrared (IR), pulses rate }\end{array}$ & ZigBee (S2C) & $\begin{array}{l}\text { Helmet with buzzer and LED } \\
\text { Alert to supervisor }\end{array}$ \\
\hline
\end{tabular}




\subsection{Surrounding Information}

Surrounding information refers to information on the underground mine environment, such as that regarding the air quality (e.g., gas concentration, temperature, humidity, and air density), collisions, and destructive events (vibrations, ultrasonic events, and ground stability). Most studies on the development of wearable systems with Arduino for surrounding information have employed a smart helmet as an actuator. One case, using a belt, was also reported to trigger a buzzer, message, and display, in addition to other forms of alarms.

Some studies have been published on the development of wearable systems for measuring the air quality in underground coal mines and providing alerts. Majee [59] proposed IoT-based automation of the safety and monitoring system operations in underground coal mines, as several workers have lost their lives owing to the absence of means of communication in emergency situations inside mines. To monitor air quality and air density via a helmet-type system, various sensors have been embedded in an Arduino Nano board (ATmega328), such as gas sensors (MQ2 for combustible gas and smoke, MQ4 for methane, butane, and natural gas, and MQ135 for sulfides, benzene, and ammonia), air density, temperature, and humidity (DHT11). This study utilized ZigBee technology and the ESP8266 Wi-Fi module as a wireless transmission network for transferring the measured data from the helmets of workers to a web server (central hub station). If a sensor measurement value exceeded the threshold limit value, as in the example in Table 5 (these values may vary depending on the study), an alarm sounded in the helmet to alert the worker. Similarly, Harshitha et al. [60] suggested a ZigBee-based intelligent helmet for coal miner safety purposes. The air quality was monitored using a gas sensor (MQ2), temperature sensor (LM35), and humidity sensor (DHT11). The three sensors were connected to an Arduino UNO board (ATmega328P) to activate a buzzer when the measurements exceeded certain levels (e.g., temperature $>40^{\circ} \mathrm{C}$ ). In addition, the measured values were transmitted to a web server at a control station using ZigBee wireless communication technology, to enable further analysis and/or monitoring.

Table 5. Example of permissible limits and threshold values for sensors (modified from Majee [59]).

\begin{tabular}{clccc}
\hline \multirow{4}{*}{ Gas } & Sensing Items & Sensor Name & Permissible Limits & Threshold Set \\
\cline { 2 - 5 } & Combustible gas and smoke & MQ-02 & Less than $30 \%$ & $30 \%$ \\
\cline { 2 - 5 } & Methane, Butane, and natural gas & MQ-4 & Less than $10 \%$ & $12 \%$ \\
\cline { 2 - 5 } & Sulfides, Benzene, and Ammonia & MQ-135 & Less than $25 \%$ & $30 \%$ \\
\hline Temperature & DHT11 & $25-40{ }^{\circ} \mathrm{C}$ & $50{ }^{\circ} \mathrm{C}$ \\
\hline Humidity & DHT11 & $15-70 \%$ & $70 \%$ \\
\hline
\end{tabular}

Based on an air quality monitoring function, Roja and Srihari [61] proposed a smart helmet system for indicating whether miners were wearing their helmets or not. Similar to the aforementioned study, they selected the Arduino UNO board as a microcontroller and used two gas sensors (MQ6 and MQ7 for $\mathrm{CO}$ and $\mathrm{CO}_{2}$, respectively). In addition, an infrared (IR) ray sensor was used to recognize the status of helmet removal. The IR sensor was laid out to transmit a continual signal from one end. If the signal was obstructed, it indicated that the mine worker was wearing a helmet; otherwise, the miner was not wearing it. For the wireless transmission of data, this study employed a GSM modem (SIM800L), a specialized type of wireless modem that works with a GSM wireless network. As actuators, a piezo buzzer on a helmet and LCD were used. To trigger the piezo buzzer, a sound generator used in electronic circuits and piezoelectric sensors were used. The measured data were displayed on the LCD.

In addition to monitoring the air quality in underground mines, some studies have reported the development of wearable systems for preventing collisions with equipment or uneven roofs. Bhuttoa et al. [62] developed a leather belt-type safety management system for measuring air quality and detecting collisions with various mining equipment or machines. Toward this aim, this study employed an Arduino Nano board and a prototype ultrasonic sensor (HC-SR04) for distance measurements 
between a worker (belt) and a machine, in addition to a gas sensor (MQ2) and temperature and humidity sensor (DHT11). The ultrasonic sensor-generated high-frequency sound waves and evaluated the echo received by the sensor for distance measurement. It could accurately measure distances ranging from $2 \mathrm{~cm}$ to $400 \mathrm{~cm}$, with a resolution of $0.3 \mathrm{~cm}$. The measurement angle was $30^{\circ}$. The experimental results showed that the detection rate by the safety device for a motor car at $3 \mathrm{~m}$ was $95 \%$, and that at $2.5 \mathrm{~m}$ was $97 \%$. The detection rates at $2,1.5,1$, and $0.5 \mathrm{~m}$ were all found to be $100 \%$. Moreover, an Arduino Nano board (ATMEGA32) connected to the ultrasonic sensor was used to acquire the data and to activate a buzzer on the belt. From these results, it can be concluded that the proposed wearable device can be used for collision avoidance.

Noorin and Suma [63] developed an IoT-based helmet-type safety management system for monitoring air quality and detecting collisions with uneven roofs in underground mines. A gas sensor (MQ4), temperature and humidity sensor (DHT11), and collision detection vibration sensor (SW420) were connected to an Arduino Nano board within a Wi-Fi wireless sensor network. Using the wireless sensor network, various sensor data with alerts were transmitted to a supervisor at a control station. The levels of temperature and humidity were communicated to the miner by displaying them on a helmet. In the case of gas, a threshold was set, and a buzzer alert was activated if the gas value was beyond the threshold limit value. Additionally, uneven roofs in underground mines can be dangerous to humans, e.g., by causing head injuries. Before a hit on a miner's head occurs, it is essential to detect it. To address this problem, a vibration sensor (SW420) was used. It was a closed-type vibration sensor and provided a clear digital output for currents above $15 \mathrm{~mA}$. The threshold was set by using a comparator with the sensor. In addition, a circuit was built in a proposed helmet for enabling the data to be provided as " 1 " or " 0 " according to the status of wearing the helmet; this was because all of the factors could only be noted if the miners were wearing the helmets.

\subsection{Human Bioinformation}

Human bioinformation refers to information related to the status of human health, such as heart rate/pulse rate (hereafter heart rate), blood pressure, glucose level, and electrocardiogram data. In fact, these types of biosensors have expanded with the increasing demand for human health monitoring. These sensors can continuously provide data on human health status, and thus, people can prevent disease. A heart rate monitoring sensor is frequently used to measure the electrical activity of the heart.

The main purpose of most studies addressing human bioinformation reviewed in this section is to monitor the heart rate using a sensor. This is because gas leakages, oxygen concentration reductions, and rapid temperature and humidity changes in underground mine environments can adversely affect the health of mine workers. Naturally, the proposed wearable systems also include functions for measuring air quality or detecting collisions in underground mine environments. Wearable systems for connecting the heart rate sensors used in the mining industry with field monitoring systems or unmanned aerial systems are difficult to develop. Furthermore, unlike systems that collect surrounding information, e.g., in the case of a wearable system for measuring human bioinformation, an actuator is configured so that the measured data is always transmitted to a supervisor or a ground control station, to check the status of the miner in real time (Figure 9).

Recently, many researchers have proposed wearable systems for connecting heart rate sensors, to check the heart rates of miners working in underground mines. Herein, these studies are classified according to the type of actuator, such as data transmission to a control center, vibrating belt, or helmet with both alarm and data transmission functions.

Priyadarsini et al. [64] developed a LabVIEW-based real-time heart rate monitoring kit for coal mine workers. They connected an ECG sensor (AD8232) to an Arduino UNO board (ATmega328) to check the electrical behavior of the heart. The ECG sensor pad was attached to human skin (e.g., the wrist or elbow) and measured the biopotentials produced by the heart (electrocardiogram) or other biopotentials from the human body. The device monitored the heart rates and analyzed the health conditions of workers using LabVIEW software. LabVIEW was used as an integration platform for 
acquiring, processing, and transmitting the data in the study. The analyzed data could be continuously monitored by the authority of the control station. If a worker was suffocating owing to an abnormal mining environment, a webpage would immediately pop up. LabVIEW continuously compared the sensed value with the predefined threshold limit value, and then provided an alert indication signal according to the heart rate of the worker. Via LabVIEW, the processed data could be transmitted to servers or webpages.

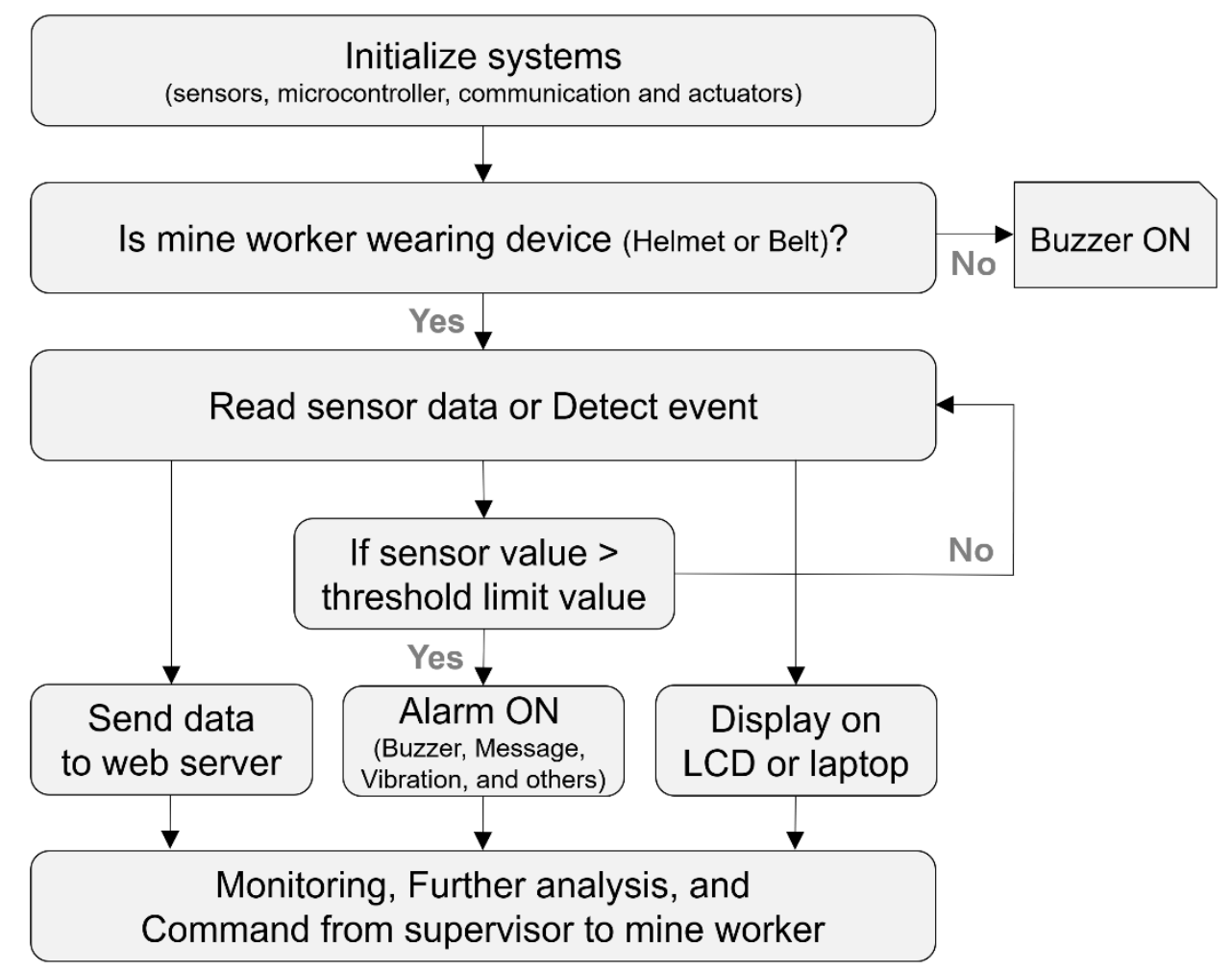

Figure 9. A flowchart showing the operating principles of the wearable safety management system.

Dudwadkar et al. [65] proposed a design for a wireless mine surveillance system using Arduino and ZigBee (XBEE) technology. They measured not only the gas concentration using the MQ35 sensor, temperature, and humidity using a DHT11 sensor, but also the heart rate, based on an IR light reflection and refraction approach. The heart rate sensor was based on the Lambert-Beer Law and obtained the pulse rate using tactile measurement. The logged data were transmitted via a ZigBee module (Xbee transmitter), and a control room at a ground station received them via another ZigBee module (Xbee receiver). Thus, the proposed system not only monitored all types of parameters under the coal mine, but could also provide an automatic alarm when environmental parameters exceeded their limitations, helping to improve the level of monitoring safety in production and to reduce accidents in coal mines.

Oliveira et al. [66] developed a prototype vibrotactile belt for navigation in an underground mine with heart rate monitoring. Unlike the aforementioned studies, this system did not consider air quality, collisions, or destructive event detection in the underground mine. This study redesigned and evaluated a tactile vocabulary via a vibrotactile belt to assist navigation in an underground mine for the safety of miners. In addition, they designed a vibrotactile display shaped like a belt. Thus, the mine worker could wear the tactile display, improving the ease of its use. Moreover, it is more appropriate to deliver tactile cues to a user's waist when the task concerns navigation. An Arduino Mega board was used to control the vibrators. During the navigation task, the heart rate data were collected using a Polar heart rate monitor interface (SEN-08661). The results of a virtual simulation of an emergency in an underground mine showed that the average heart rate increased between trials for all users. As the users performed the navigation in a standing position, the variation in their heart 
rate could have been associated with fatigue or anxiety. Nevertheless, heart rate data could be used to indicate important characteristics for a sense of immersion in virtual environments.

Some studies have designed smart helmets for measuring and monitoring both the air quality in the underground mine and the heart rates of mine workers. Alam et al. [29] designed a prototype intelligent helmet for mine workers, intended for monitoring heart rates and air quality. The system comprised three environmental sensors related to gas (MQ5), temperature, and humidity (HSM-20G) in an underground mine and heartbeat detection sensor (ear clip kit). This kit was highly sensitive, yet consumed little power. The measured heart rate could be displayed on a screen via a serial port and could be saved for further analysis. The Arduino Mega (ATmega2560) microcontroller and ZigBee modules were selected to send or receive all of the electrical signals. After rapid changes in the environmental parameters in underground mines, it was possible to alert the workers via a buzzer on the helmet, and the time series signals could be displayed on an LCD or laptop at a ground station by the ZigBee module.

In a similar way, Dewarkar et al. [67] designed a smart helmet system for the security of coal mine workers. The system was divided into a transmitter section and receiving section. An Arduino (ATmega328p) microcontroller was connected to two environmental sensors for monitoring carbon monoxide and temperature inside the coal mine, a pulse rate sensor for monitoring the heartbeat of miners, and a global positioning system (GPS) sensor for locating the position of workers. For the wireless network, HC12 (a half-duplex communication module) was used for the data transmitter and receiver. A display screen was used to display the parameters. A buzzer was designed to trigger a buzzer under harmful and dangerous conditions. Sanjay et al. [68] developed a helmet-type safety management system for destructive event detection, as well as for detecting air quality and heart rates of mine workers. However, the system design, including the types of sensors (air quality, such as for gas, humidity, atmospheric pressure, and temperature; destructive event detection, such for as falling rocks; heart rate), microcontroller (Arduino Nano), communicator (ZigBee S2C), and actuators (buzzer, LED indications on the helmet, and alerts to supervisors) were similar to those in previous studies. The system was developed by programming based on Arduino IDE and Python.

\section{Arduino in Autonomous Mine Systems}

Mining is one of the most hazardous and labor-intensive industries [69]. Therefore, the mining industry has tried to use autonomous systems such as automated haul trucks, monitoring robots, and underground UAVs to effectively enhance safety and productivity in mining operations. Automation in mine environments can play a critical role in improving worker safety and mine productivity. Arduino has been used in the mining industry to develop an initial prototype for supporting mine operations (Table 6).

Ledange and Mathurkar [70] developed a robot-based underground coal mine monitoring system using Arduino. The system consisted of two parts (transmitter and receiver). In the transmitter, different sensors such as MQ2 for gas, DHT11 for temperature, and ADXL335 for tilt were attached to an Arduino UNO board to monitor the underground mine environment in real time. In addition, a ZigBee wireless communication module (Xbee) was used to send the monitoring data to the receiver. A buzzer module was used to trigger a sound when the measured values obtained from the sensors exceeded threshold levels. The transmitter was mounted on a small rear wheel-type robot with DC motors, controlled by a motor driver IC L293D. In the receiver part, the keypad and ZigBee (Xbee) modules were connected to the Arduino UNO board to receive data from the transmitter and to control the movement of the robot. The developed robot system was tested only in the laboratory, and no field test results were presented. 
Table 6. Summary of Arduino applications for developing autonomous mine systems.

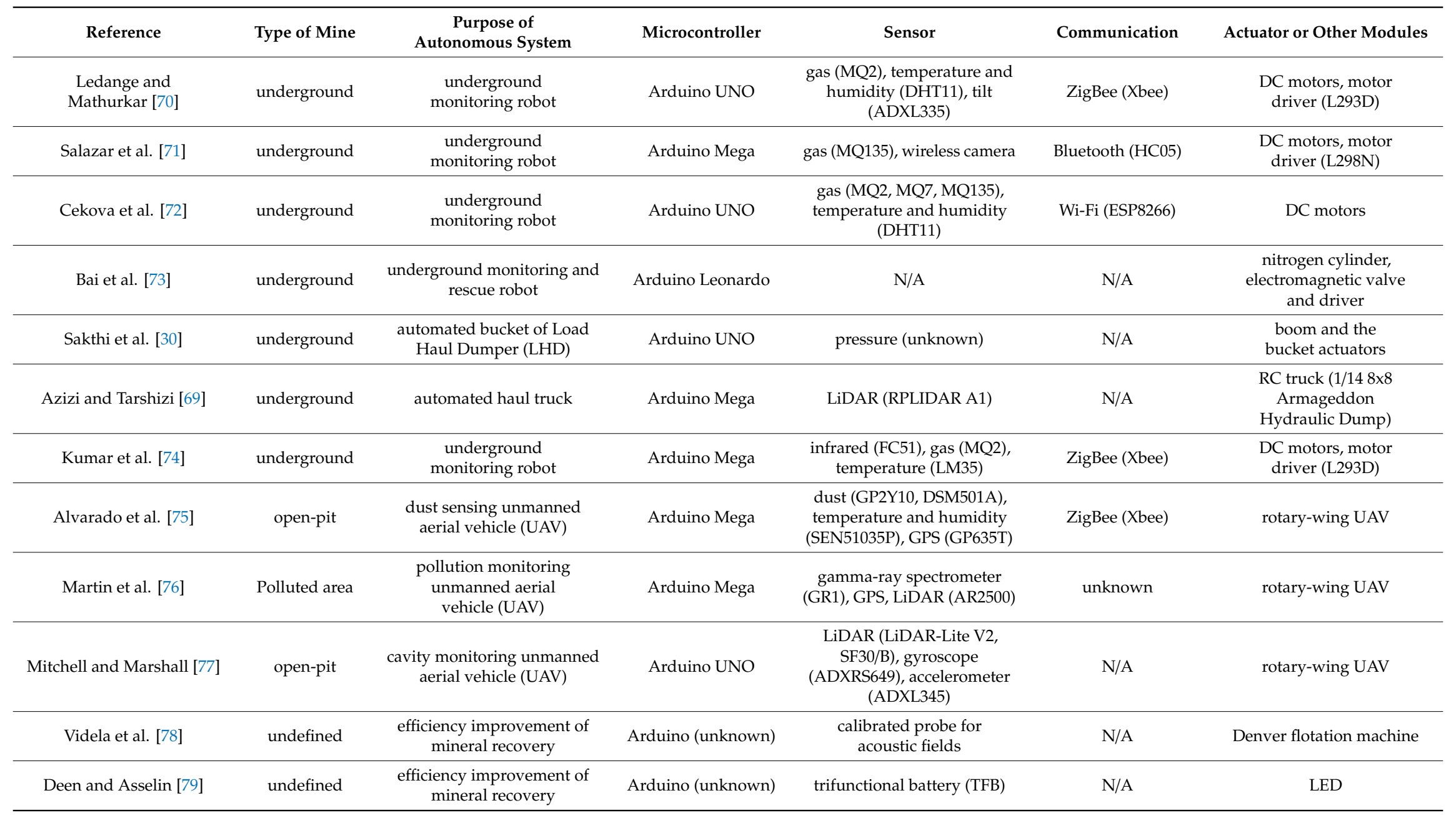


In a similar study, Salazar et al. [71] developed an autonomous robot for accessing dangerous areas by remote control and for measuring the concentrations of harmful and flammable gases such as carbon monoxide $(\mathrm{CO})$, carbon dioxide $\left(\mathrm{CO}_{2}\right)$, methane $\left(\mathrm{CH}_{4}\right)$, and nitrates $(\mathrm{NOx})$. A motor driver module L298N, Bluetooth module HC05, and gas sensor MQ135 were used and attached to the Arduino Mega to implement the robot. A wireless camera was mounted on the robot to support remote operation. The robot was only tested in the laboratory with a remote distance of up to $10 \mathrm{~m}$, owing to the limited range of wireless communication provided by the Bluetooth module. Cekova et al. [72] used an Arduino UNO board to develop a mobile sensor robot for detecting toxic gases in underground mines. Various sensors were attached to an Arduino UNO, such as DHT11 for temperature and humidity, MQ2 for $\mathrm{CH}_{4}, \mathrm{MQ7}$ for $\mathrm{CO}$, and MQ135 for $\mathrm{CO}_{2}$. A Wi-Fi module (ESP8266 SP8266) for facilitating $\mathrm{TCP} / \mathrm{IP}$ wireless communication was integrated with the board. The robot could be remotely controlled using a smartphone. The developed robot was tested in a nonmetallic surface mine. The concentration of toxic gases generated during an explosion owing to blasting was measured in real time, at a distance of $100 \mathrm{~m}$. However, a field test was not performed in an underground mine.

To detect gas from coal mines and carry out rescue operations, Bai et al. [73] developed an experimental prototype of a hexapod robot that could be more precisely controlled. This robot used a high-pressure nitrogen cylinder as a power source, and the leg mechanism had three degrees of freedom to allow straight walking and turning motions. The robot was driven by a cylinder that was controlled by an electromagnetic valve. An Arduino Leonardo with a magnetic valve drive board was used to compile the control circuit of the electromagnetic valve. In addition, the gyroscope was used to measure the changing signals of the joint rotation angle and angular velocity. However, this prototype was only tested in a laboratory environment.

Sakthi et al. [30] used an Arduino UNO to test an automated bucket control module for an LHD used in underground mines. The bucket control module incorporated two major subsystems to be controlled: boom and bucket actuators. A pressure sensor was connected to the Arduino UNO board, so that the bucket control module could sense the forces in the boom actuation to control the velocity of the bucket actuator. An indoor test using a miniature LHD was performed with the bucket control module.

The localization and tracking of moving objects are also critical issues in the development of unmanned robots for underground mines. Traditional techniques based on GPS and other location sensors have been widely utilized in surface mines for simultaneous localization and mapping. However, a different approach is necessary in an underground environment, as GPS does not work in such locations. Azizi and Tarshizi [69] developed a lab-scale automated haul truck that could be autonomously controlled and navigated along an underground tunnel. LiDAR sensors were integrated with an Arduino Mega to estimate the autonomous truck position, using a navigation algorithm based on a triangulation method. The simulation results showed the effectiveness of the developed navigation and control algorithms; however, the study should be extended to consider real-size mine haul trucks. Kumar et al. [74] proposed a prototype for an underground localization system for an unmanned robot using an Arduino Mega board with IR sensors (FC51) for obstacle detection, a gas sensor (MQ2) for detecting the presence of harmful gases, and a temperature sensor (LM35) for gauging the temperature. A ZigBee module (Xbee) was used to transmit data from the system to a base station (desktop PC). The localization of the robot was conducted by only considering the moving direction (north, south, east, and west), as controlled by a motor driver. An indoor experiment showed that the system could track the robot with reasonable precision. However, it was too simple to be used in real underground mines, as only four types of moving directions were used for localization. Additional sensors and mapping techniques are required to improve the system.

The Arduino has also been used to develop a small UAV for monitoring dust particles after blasting at open-pit mines [75]. Two dust sensors, GP2Y10 (SHARP) and DSM501A (Samyoung), a temperature and humidity sensor (SEN51035P), GPS logger (GP635T), and ZigBee module (Xbee) were connected to an Arduino Mega board to develop a low-weight and size-constrained dust sensing 
system for mounting on a small UAV. Figure 10 shows the system architecture for the modular dust sensor in detail. All data collected from the dust sensors were transmitted and logged on a ground station in real time. The Arduino-based dust sensing system was mounted on a multirotor UAV, and a field test was conducted using talcum powder (composed of 0.2.0.3 mass fraction with a particle diameter no greater than $10 \mu \mathrm{m}$ ) lifted into the atmosphere (Figure 11).

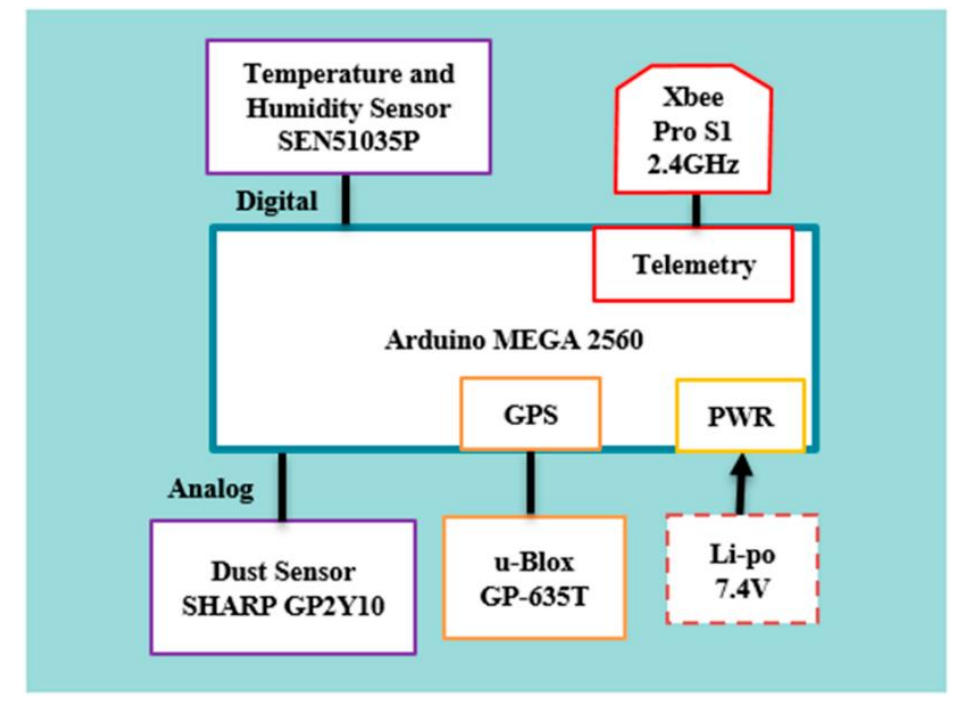

Figure 10. System architecture for the modular dust sensor [75].

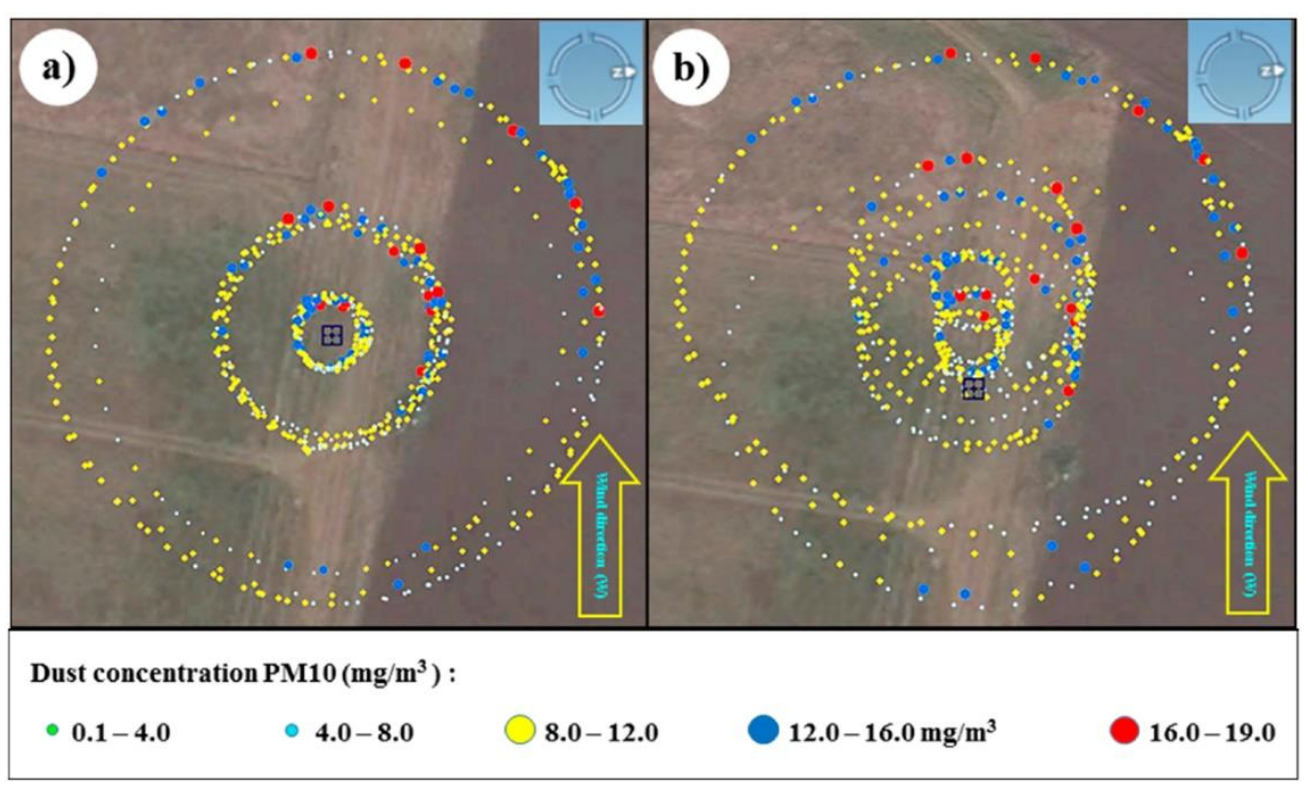

Figure 11. Flight path and PM10 concentrations monitored with the dust sensing system mounted on an unmanned aerial vehicle (UAV) quadcopter [75]. (a) Top view; (b) side view.

In combination with a UAV, Arduino can also be used to detect areas polluted by mining activities. For example, in Cornwall, England, mining of uranium has resulted in a significant amount of radioactive contamination in the surrounding area. To effectively detect polluted areas, Martin et al. [76] combined a UAV with gamma radiation mapping technology. To construct an unmanned radiation detection system, a gamma-ray spectrometer was used with a GPS module to measure the spectrum of incident radiation energy. The height of the device was also recorded using a laser rangefinder system (AR2500, Acuity), and these data streams were combined using an Arduino 
Mega. The data were stored locally on the instrument itself and concurrently transmitted to a remote base station.

A cavity monitoring system (CMS) has been utilized in underground mines to collect information regarding mine stopes, openings, ore passes, and any other cavity with limited accessibility [80]. Mitchell and Marshall [77] used an Arduino UNO board to develop a CMS based on UAVs. The system was designed as an autorotating surveying system using a single-point LiDAR sensor. A rotating falling body could gather 3D survey data in underground cavities, as shown in Figure 12. To develop the CMS, the Arduino UNO board was integrated with a horizontal facing LiDAR sensor (LiDAR-Lite V2) for surveying the cavity walls during descent and a vertical facing LiDAR sensor (SF30/B) for monitoring the vertical position. In addition, a gyroscope (ADXRS649) and an accelerometer (ADXL345) were used to monitor the angular velocity and acceleration, respectively, along the vertical axis during the flight of the UAV. Figure 13 shows the electronics used for developing the initial prototype autorotating cavity surveyor in Mitchell and Marshall [77]. The system was tested in the laboratory; however, more complicated conditions in a real underground cavity were not considered, such as air currents from ventilation, and harsh humidity and temperature conditions.

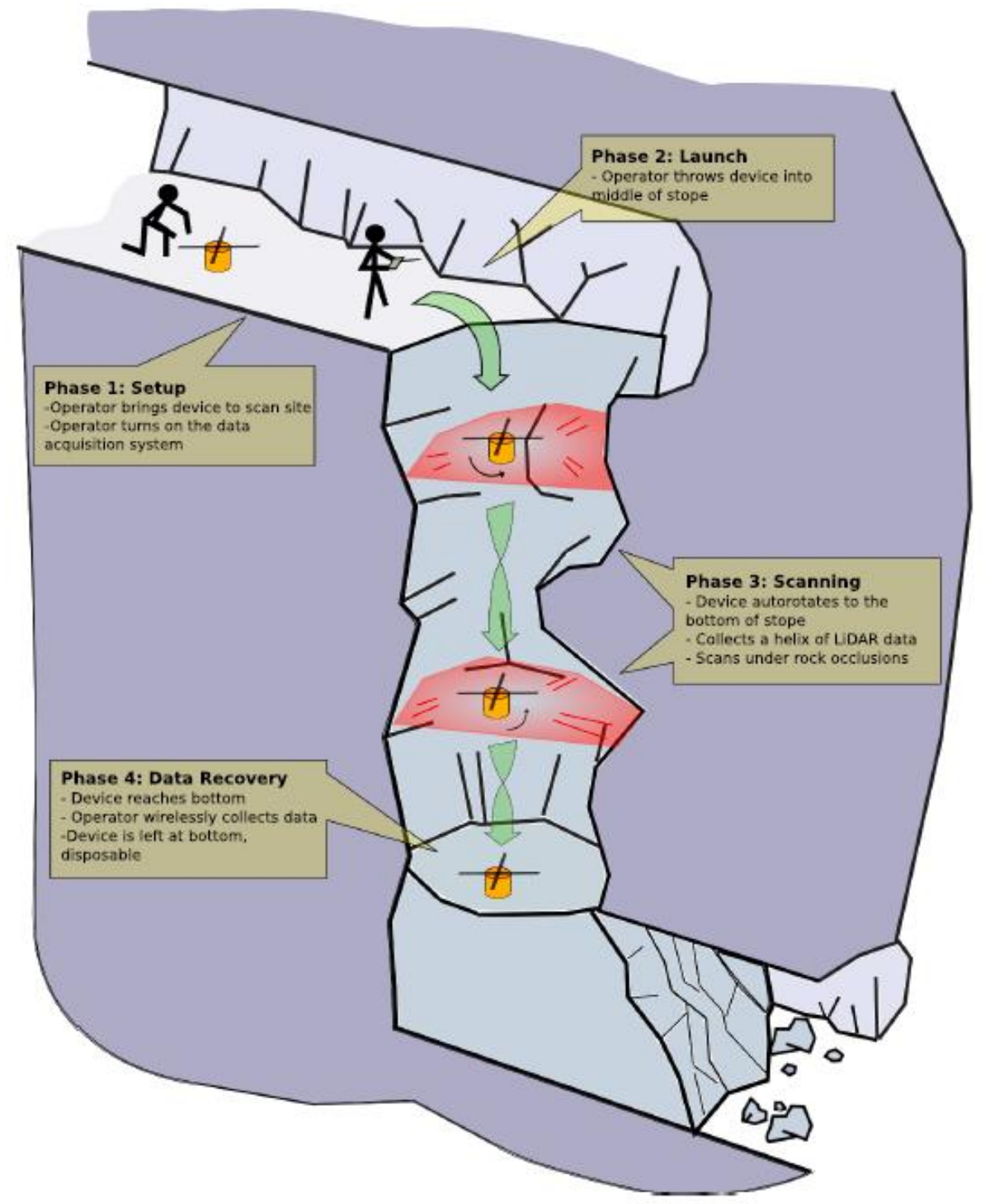

Figure 12. Operational phases including setup, launch, scanning, and data recovery for a potentially disposable auto-rotating cavity surveying device [77]. (License Number 4851090213631). 

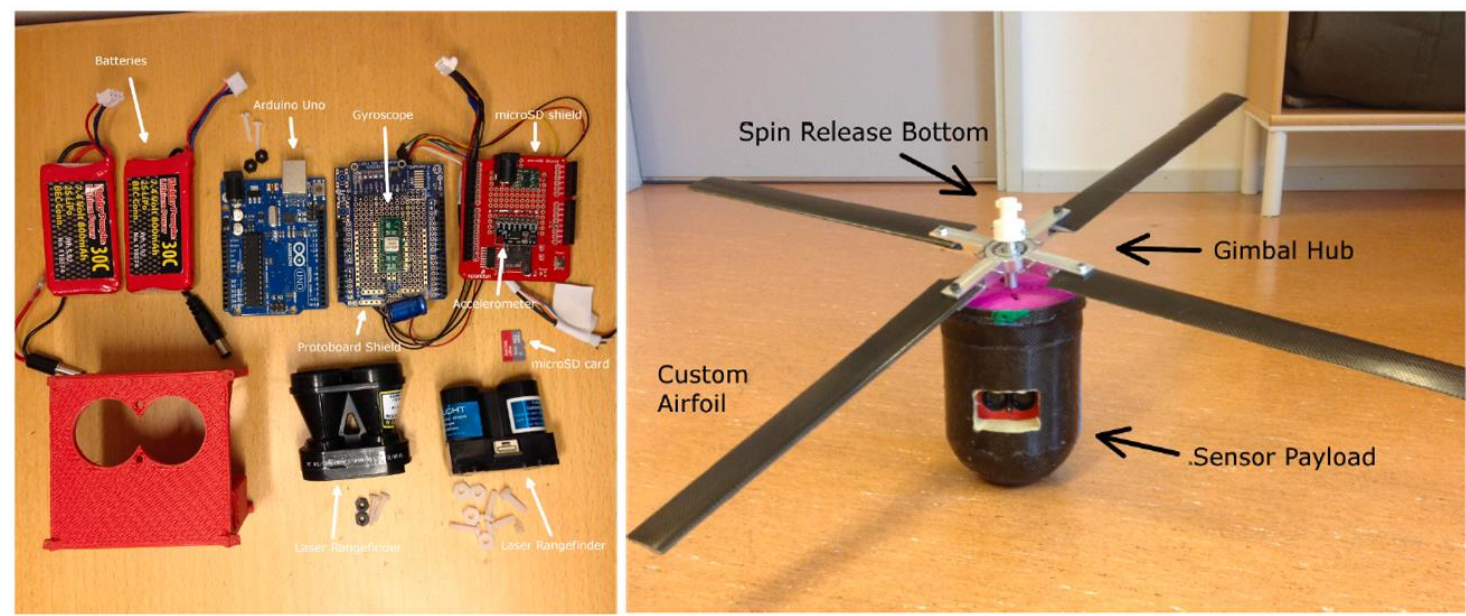

Figure 13. Electronics used to monitor the position/orientation of the device and collect cavity range measurements (left), and initial prototype auto-rotating cavity surveyor (right) [77]. (License Number 4851090213631).

The deterioration of mineral grades is an important issue to be overcome in the mining industry, as the development of mines has continued over time. To solve this problem, techniques for improving recovery efficiency have been studied. Arduinos are being used in part as an auxiliary role to help with these studies. Videla et al. [78] conducted a study to improve the flotation of copper sulfides inside tailings using ultrasounds. Ultrasounds can improve the overall recovery by removing the oxidized layer from the particle surface and aiding in desliming. The 'Denver' flotation cell was modified to control the ultrasound in the flotation test. A calibrated probe designed to measure cavitating acoustic fields converted external mechanical disturbances into electrical signals. These signals were processed through the code input to the Arduino board. As a result, the distribution of the absolute critical pressure inside the Denver flotation cell could be analyzed. $\mathrm{Zn}$ and $\mathrm{Cu}$ are often mineralized together and both the $\mathrm{Cu}$ extraction from $\mathrm{CuFeS}_{2}$ and the electrodeposition of $\mathrm{Zn}$ are highly energy-intensive processes. To increase economic efficiency, Deen and Asselin [79] integrated the two energy-intensive metallurgical processes into a battery-like device called a trifunctional battery (TFB), which is capable of extracting $\mathrm{Cu}$ as well as storing energy. To demonstrate the practical use of the TFB, the cell was charged and connected to an LED mounted on the Arduino board. The Arduino measures the voltage of the cell, and the LED blinks when the voltage falls below a threshold value.

\section{Discussion}

In this paper, research cases employing Arduino in mining were collected, and the statistical trends were analyzed. Arduino has the advantage of being a microcontroller that can be applied to various environments and tools. However, in the mining field, its use has been biased towards field monitoring systems ( 25 papers) more than wearable systems (11 papers) and autonomous systems (12 papers). In addition, it was found that in all systems, Arduino was mainly applied in underground mines (total 36 papers) rather than open-pit mines (total of seven papers, Table 7). In particular, in the case of wearable systems, all studies (11 papers) were conducted for applications in underground mines. In the field monitoring systems, some studies were conducted to acquire geological information of open-pit mines (five papers) or air quality information of polluted areas (two papers), but there were more cases addressing underground mines (18 papers). In the autonomous system field, there were studies on automating work in open-pit mines (two papers) as well as underground mine studies (seven papers), but the absolute number was not large. The reason why the number of studies related to underground mines is higher than that for open-pit mines is attributed to the communication technologies and cost-saving advantages of Arduino. In underground mines, there have been difficulties in the use of equipment and safety problems relating to open-pit mines, owing to communication difficulties. 
However, Arduino is able to acquire information and perform communication at a low cost; thus, it can be understood why research using the Arduino in underground mines has increased. In contrast, as existing equipment can be used in open-pit mines, there are fewer research cases using the Arduino.

Table 7. Reviewed literature classified by mine type.

\begin{tabular}{ccccc}
\hline Mine Type & $\begin{array}{c}\text { Field Monitoring } \\
\text { Systems }\end{array}$ & $\begin{array}{c}\text { Wearable } \\
\text { Systems }\end{array}$ & $\begin{array}{c}\text { Autonomous } \\
\text { Mine Systems }\end{array}$ & $\begin{array}{c}\text { Sum } \\
\text { (Percentage) }\end{array}$ \\
\hline Underground & $18(37.5 \%)$ & $11(22.9 \%)$ & $7(14.6 \%)$ & $36(75.0 \%)$ \\
\hline Open-pit & $5(10.4 \%)$ & $0(0.0 \%)$ & $2(4.2 \%)$ & $7(14.6 \%)$ \\
\hline Polluted area & $2(4.2 \%)$ & $0(0.0 \%)$ & $1(2.1 \%)$ & $3(6.2 \%)$ \\
\hline Undefined & $0(0.0 \%)$ & $0(0.0 \%)$ & $2(4.2 \%)$ & $2(4.2 \%)$ \\
\hline Sum (Percentage) & $25(52.1 \%)$ & $11(22.9 \%)$ & $12(25.0 \%)$ & $48(100.0 \%)$ \\
\hline
\end{tabular}

The usage of Arduino according to specific purposes is summarized in Table 8. The sum of the statistically analyzed items and the literature reviewed in this study do not necessarily match; as in some papers, two or more items are related. For example, as air quality, temperature, and humidity are very important factors that directly affect safety in mines (especially underground mines), there are cases of atmospheric monitoring in all three types of systems. Field monitoring systems have been used to monitor geotechnical mining information such as information regarding the slope (four papers), vibration (one paper), borehole (one paper), and mine roof (one paper), as well as atmospheric data. However, there have not been many cases. In addition, in wearable systems, most of the research is related to atmospheric monitoring (10 papers). Other important observations are whether a helmet is worn (two papers), whether a collision has occurred (three papers), and the heart rate (six papers) or location (two papers) of a mine worker. In autonomous systems, atmospheric monitoring through a robot is an important research topic (six papers). In addition, Arduino has been used to control the operation of machines (seven papers), or to monitor a mine environment in combination with a UAV (three papers).

Table 9 summarizes the Arduino types employed in the reviewed articles, according to the system type. There are many types of Arduino devices, but the Arduino UNO, Nano, and Mega were used in most studies. Although the Arduino UNO has been used in the most studies (22 papers), the use of Arduino Nano has also been reported in wearable systems, where a relatively small size may be advantageous. In addition, there have been some papers utilizing an Arduino Mega in autonomous systems that require connection to a variety of sensors and actuators. In many studies, various sensors are used to perform monitoring, regardless of the system type. This is because the Arduino can be easily connected to various sensors and can record and transmit the values obtained from the sensors. The statistics of the sensor types in the reviewed papers are summarized in Table 10. Gas, temperature, and humidity sensors are frequently used as atmospheric monitoring is the most common topic. In addition, it can be seen that various sensors suitable for the research purpose(s) were used. The information acquired through monitoring is often transmitted through various communication technologies that can be combined with Arduino. Table 11 shows the statistics of the applied communication techniques. ZigBee, which makes it easy to build WSNs, was used the most frequently (18 papers), and technologies such as GSM, Wi-Fi, and Bluetooth were used according to each need and purpose. In addition, actuators such as buzzers, LCDs, and LEDs were used to promptly respond to monitoring results. In another example, in autonomous systems, the actuators related to the control of the machine were important. Table 12 summarizes the actuators in the reviewed papers. 
Table 8. Reviewed literature classified by application purpose.

\begin{tabular}{ccccc}
\hline Purpose & $\begin{array}{c}\text { Field Monitoring } \\
\text { Systems }\end{array}$ & $\begin{array}{c}\text { Wearable } \\
\text { Systems }\end{array}$ & $\begin{array}{c}\text { Autonomous } \\
\text { Mine Systems }\end{array}$ & $\begin{array}{c}\text { Sum } \\
\text { (Percentage) }\end{array}$ \\
\hline Atmospheric monitoring & $18(26.9 \%)$ & $10(14.9 \%)$ & $6(9.0 \%)$ & $34(50.7 \%)$ \\
\hline Slope monitoring & $4(6.0 \%)$ & $0(0.0 \%)$ & $0(0.0 \%)$ & $4(6.0 \%)$ \\
\hline Vibration monitoring & $1(1.5 \%)$ & $0(0.0 \%)$ & $0(0.0 \%)$ & $1(1.5 \%)$ \\
\hline Borehole monitoring & $1(1.5 \%)$ & $0(0.0 \%)$ & $0(0.0 \%)$ & $1(1.5 \%)$ \\
\hline Roof monitoring & $1(1.5 \%)$ & $0(0.0 \%)$ & $0(0.0 \%)$ & $1(1.5 \%)$ \\
\hline Helmet wearing detection & $0(0.0 \%)$ & $2(3.0 \%)$ & $0(0.0 \%)$ & $2(3.0 \%)$ \\
\hline Collision/event detection & $0(0.0 \%)$ & $3(4.5 \%)$ & $0(0.0 \%)$ & $3(4.5 \%)$ \\
\hline Heart rate (pulse) monitoring & $0(0.0 \%)$ & $6(9.0 \%)$ & $0(0.0 \%)$ & $6(9.0 \%)$ \\
\hline Navigation/ position monitoring & $0(0.0 \%)$ & $2(3.0 \%)$ & $1(1.5 \%)$ & $3(4.5 \%)$ \\
\hline Machine/robot control & $0(0.0 \%)$ & $0(0.0 \%)$ & $7(10.4 \%)$ & $7(10.4 \%)$ \\
\hline UAV-based monitoring & $0(0.0 \%)$ & $0(0.0 \%)$ & $3(4.5 \%)$ & $3(4.5 \%)$ \\
\hline $\begin{array}{c}\text { Efficiency improvement of } \\
\text { mineral recovery }\end{array}$ & $0(0.0 \%)$ & $0(0.0 \%)$ & $2(3.0 \%)$ & $2(3.0 \%)$ \\
\hline Sum & $25(37.3 \%)$ & $23(34.3 \%)$ & $19(28.4 \%)$ & $67(100.0 \%)$ \\
\hline
\end{tabular}

Table 9. Reviewed literature classified by Arduino type.

\begin{tabular}{ccccc}
\hline Arduino Type & $\begin{array}{c}\text { Field Monitoring } \\
\text { Systems }\end{array}$ & $\begin{array}{c}\text { Wearable } \\
\text { Systems }\end{array}$ & $\begin{array}{c}\text { Autonomous } \\
\text { Mine Systems }\end{array}$ & $\begin{array}{c}\text { Sum } \\
\text { (Percentage) }\end{array}$ \\
\hline UNO & $14(28.6 \%)$ & $4(8.2 \%)$ & $4(8.2 \%)$ & $22(44.9 \%)$ \\
\hline Mega & $8(16.3 \%)$ & $2(4.1 \%)$ & $5(10.2 \%)$ & $15(30.6 \%)$ \\
\hline Nano & $2(4.1 \%)$ & $5(10.2 \%)$ & $0(0.0 \%)$ & $7(14.3 \%)$ \\
\hline Due & $1(2.0 \%)$ & $0(0.0 \%)$ & $0(0.0 \%)$ & $1(2.0 \%)$ \\
\hline Leonardo & $0(0.0 \%)$ & $0(0.0 \%)$ & $1(2.0 \%)$ & $1(2.0 \%)$ \\
\hline Etc. & $1(2.0 \%)$ & $0(0.0 \%)$ & $2(4.1 \%)$ & $3(6.1 \%)$ \\
\hline Sum & $26(53.1 \%)$ & $11(22.4 \%)$ & $12(24.5 \%)$ & $49(100.0 \%)$ \\
\hline
\end{tabular}

Table 10. Reviewed literature classified by sensor.

\begin{tabular}{ccccc}
\hline Sensor & $\begin{array}{c}\text { Field Monitoring } \\
\text { Systems }\end{array}$ & Wearable Systems & $\begin{array}{c}\text { Autonomous } \\
\text { Mine Systems }\end{array}$ & Sum (Percentage) \\
\hline Gas & $17(15.9 \%)$ & $9(8.4 \%)$ & $4(3.7 \%)$ & $30(28.0 \%)$ \\
\hline Temperature & $9(8.4 \%)$ & $8(7.5 \%)$ & $4(3.7 \%)$ & $21(19.6 \%)$ \\
\hline Humidity & $5(4.7 \%)$ & $7(6.5 \%)$ & $3(2.8 \%)$ & $15(14.0 \%)$ \\
\hline Heart beat & $1(0.9 \%)$ & $6(5.6 \%)$ & $0(0.0 \%)$ & $7(6.5 \%)$ \\
\hline Accelerometer or vibration & $2(1.9 \%)$ & $1(0.9 \%)$ & $2(1.9 \%)$ & $5(4.7 \%)$ \\
\hline Pressure & $1(0.9 \%)$ & $1(0.9 \%)$ & $1(0.9 \%)$ & $3(2.8 \%)$ \\
\hline LiDAR & $1(0.9 \%)$ & $0(0.0 \%)$ & $3(2.8 \%)$ & $4(3.7 \%)$ \\
\hline IR & $0(0.0 \%)$ & $2(1.9 \%)$ & $1(0.9 \%)$ & $3(2.8 \%)$ \\
\hline TDR & $3(2.8 \%)$ & $0(0.0 \%)$ & $0(0.0 \%)$ & $3(2.8 \%)$ \\
\hline Air flow or density & $1(0.9 \%)$ & $1(0.9 \%)$ & $0(0.0 \%)$ & $2(1.9 \%)$ \\
\hline Ultrasonic & $1(0.9 \%)$ & $1(0.9 \%)$ & $1(0.9 \%)$ & $3(2.8 \%)$ \\
\hline GPS & $0(0.0 \%)$ & $1(0.9 \%)$ & $2(1.9 \%)$ & $3(2.8 \%)$ \\
\hline Gyroscope & $0(0.0 \%)$ & $0(0.0 \%)$ & $1(0.9 \%)$ & $1(0.9 \%)$ \\
\hline Etc. & $1(0.9 \%)$ & $1(0.9 \%)$ & $5(4.7 \%)$ & $7(6.5 \%)$ \\
\hline Sum & $42(39.3 \%)$ & $38(35.5 \%)$ & $27(25.2 \%)$ & $107(100.0 \%)$ \\
\hline
\end{tabular}


Table 11. Reviewed literature classified by communication.

\begin{tabular}{ccccc}
\hline Communication & $\begin{array}{c}\text { Field Monitoring } \\
\text { Systems }\end{array}$ & $\begin{array}{c}\text { Wearable } \\
\text { Systems }\end{array}$ & $\begin{array}{c}\text { Autonomous } \\
\text { Mine Systems }\end{array}$ & $\begin{array}{c}\text { Sum } \\
\text { (Percentage) }\end{array}$ \\
\hline ZigBee & $10(26.3 \%)$ & $5(13.2 \%)$ & $3(7.9 \%)$ & $18(47.4 \%)$ \\
\hline GSM & $5(13.2 \%)$ & $1(2.6 \%)$ & $0(0.0 \%)$ & $6(15.8 \%)$ \\
\hline Wi-Fi & $2(5.3 \%)$ & $2(5.3 \%)$ & $1(2.6 \%)$ & $5(13.2 \%)$ \\
\hline Bluetooth & $3(7.9 \%)$ & $0(0.0 \%)$ & $1(2.6 \%)$ & $4(10.5 \%)$ \\
\hline RF & $1(2.6 \%)$ & $1(2.6 \%)$ & $0(0.0 \%)$ & $2(5.3 \%)$ \\
\hline Etc. & $1(2.6 \%)$ & $1(2.6 \%)$ & $1(2.6 \%)$ & $3(7.9 \%)$ \\
\hline Sum & $22(57.9 \%)$ & $10(26.3 \%)$ & $6(15.8 \%)$ & $38(100.0 \%)$ \\
\hline
\end{tabular}

Table 12. Reviewed literature classified by actuator or other modules.

\begin{tabular}{ccccc}
\hline $\begin{array}{c}\text { Actuator or Other } \\
\text { Modules }\end{array}$ & $\begin{array}{c}\text { Field Monitoring } \\
\text { Systems }\end{array}$ & $\begin{array}{c}\text { Wearable } \\
\text { Systems }\end{array}$ & $\begin{array}{c}\text { Autonomous } \\
\text { Mine Systems }\end{array}$ & $\begin{array}{c}\text { Sum } \\
\text { (Percentage) }\end{array}$ \\
\hline Buzzer & $5(11.6 \%)$ & $8(18.6 \%)$ & $0(0.0 \%)$ & $13(30.2 \%)$ \\
\hline LCD & $3(7.0 \%)$ & $3(7.0 \%)$ & $0(0.0 \%)$ & $6(14.0 \%)$ \\
\hline Motors or motor driver & $1(2.3 \%)$ & $0(0.0 \%)$ & $4(9.3 \%)$ & $5(11.6 \%)$ \\
\hline LED & $1(2.3 \%)$ & $2(4.7 \%)$ & $1(2.3 \%)$ & $4(9.3 \%)$ \\
\hline UAV & $0(0.0 \%)$ & $0(0.0 \%)$ & $3(7.0 \%)$ & $3(7.0 \%)$ \\
\hline Vacuum pump & $1(2.3 \%)$ & $0(0.0 \%)$ & $0(0.0 \%)$ & $1(2.3 \%)$ \\
\hline Centrifugal fan & $1(2.3 \%)$ & $0(0.0 \%)$ & $0(0.0 \%)$ & $1(2.3 \%)$ \\
\hline Vibrotactile belt & $0(0.0 \%)$ & $1(2.3 \%)$ & $0(0.0 \%)$ & $1(2.3 \%)$ \\
\hline RC truck & $0(0.0 \%)$ & $0(0.0 \%)$ & $1(2.3 \%)$ & $1(2.3 \%)$ \\
\hline Etc. & $3(7.0 \%)$ & $1(2.3 \%)$ & $4(9.3 \%)$ & $8(18.6 \%)$ \\
\hline Sum & $15(34.9 \%)$ & $15(34.9 \%)$ & $13(30.2 \%)$ & $43(100.0 \%)$ \\
\hline
\end{tabular}

\section{Conclusions}

In this review, we have presented numerous studies utilizing open-source hardware Arduino platforms in the mining industry. A total of 48 recently published articles were identified, and the detailed contents regarding the applications of Arduino were analyzed for the literature review. It was confirmed that many of the studies reviewed in this paper were conducted in developing countries rather than developed countries. This trend may be attributed to the cost-effectiveness of Arduino. In the mining industry, the utilization of microcontrollers, such as Arduinos, has increased rapidly in recent years. These studies will serve as the basis for the development of smart mining and further advanced use of microcontrollers in the future. For systematic reviews, the articles were classified under three topics, considering the purpose of the applications: field monitoring, wearable systems, and autonomous systems.

For field monitoring, a number of applications of fixed monitoring systems based on Arduino were reported. These studies can be divided into the monitoring of air quality information and geotechnical information. In underground mines, various gas, temperature, and humidity sensors are mainly used to acquire air quality data. Generally, the acquired data is transmitted outside the underground mine through a WSN and gateway. Some studies have been conducted to predict possible risks through the interpretation of the acquired monitoring data. In addition, studies have been conducted on ventilation networks and evacuation to help mineworkers respond appropriately to potential hazards. Some studies have been applied to real mines, but otherwise, most of the studies have been conducted in laboratory environments. There have been some Arduino-based articles 
addressing slope stability and roof-falls in mines. Although the accuracy may be lower than that of existing expensive instruments, monitoring sensors combined with Arduino have advantages in being low cost and having high efficiency; therefore, multiple sensors can be installed in the field. In addition, as the developer can easily customize the product, various attempts can be made, and it can be easily integrated with other analysis methods. However, as there are few applications for real mines, verification at a mine site is necessary to improve accuracy and effectiveness.

A wearable system for mining workers developed using an Arduino board, various sensors, and wireless networks was proven to be useful for gas detection, air quality measurement, proximity detection between miners and machines, collapse notifications, and heart rate monitoring in an underground (mostly coal) mining environment. As the wearable system is worn by miners, it has the advantage of measuring the environmental parameters that the miners face more accurately than other systems. Therefore, if risks are identified at early stages, mine workers can take immediate action to avoid accidents. In particular, real-time monitoring of the heart rates and health of mine workers using biosensors can be considered as the most effective application of an Arduino-based wearable system as doing so with field-based or UAV systems remains difficult. However, as there are various commercially available wearable devices (e.g., smart glasses) and biosensors, it is necessary to develop diverse applications for enhancing work efficiency and securing the safety of miners.

Many applications of Arduino have been reported in the literature. For example, Arduino was useful for developing initial prototypes of autonomous mine systems such as underground monitoring robots, automated buckets for LHDs, automated haul trucks, and UAVs for dust sensing and cavity monitoring. In these applications, the Arduino UNO or Mega board was integrated with various sensors for measuring gas, temperature, humidity, tilt, pressure, distance, infrared, dust, acceleration, etc. The ZigBee wireless communication module (Xbee) is often used to send data from the transmitter to the receiver. Although the Arduino-based prototype systems were tested in the laboratory, few field test results have been reported in the literature. A real mining site presents more complications than the laboratory environment; therefore, further research is necessary to use these autonomous mine systems in the real world.

Author Contributions: All the authors gathered, reviewed, analyzed and wrote the published literature; Y.C. implemented the final work for the paper submission. All authors have read and agreed to the published version of the manuscript.

Funding: This work was supported by Basic Science Research Program through the National Research Foundation of Korea (NRF) funded by the Ministry of Science and ICT (2020R1G1A1010789).

Conflicts of Interest: The authors declare no conflicts of interest.

\section{References}

1. Smart Mining. Available online: https://www.riotinto.com/about/innovation/smart-mining (accessed on 5 July 2020).

2. How the Internet-of-Things Is Transforming Mining. Available online: http://www.clresearch.com/research/ detail.cfm?guid=A5E6FEAF-3048-79ED-99C9-EA62EBCCD605 (accessed on 5 July 2020).

3. Open Source Software for Industry 4.0. Available online: https://iot.eclipse.org/community/resources/whitepapers/industry40 (accessed on 10 March 2020).

4. The Future with Open-Source Hardware. Available online: http://www.digitalqatar.qa/en/2015/02/19/thefuture-with-open-source-hardware (accessed on 5 April 2020).

5. Open Source Organizations. Available online: https://opensource.com/resources/organizations (accessed on 5 April 2020).

6. What Is Open Hardware? Available online: https://opensource.com/resources/what-open-hardware (accessed on 15 March 2020).

7. Damjanovic-Behrendt, V.; Behrendt, W. An open source approach to the design and implementation of Digital Twins for Smart Manufacturing. Int. J. Comput. Integr. Manuf. 2019, 32, 366-384. [CrossRef] 
8. Fisher, D.K.; Gould, P.J. Open-source hardware is a low-cost alternative for scientific instrumentation and research. Mod. Instrum. 2012, 1, 8-20. [CrossRef]

9. Hopkins, M.A.; Kibbe, A.M. Open-source hardware in controls education. Comput. Educ. J. 2014, 5, 62-70.

10. Reguera, P.; García, D.; Domínguez, M.; Prada, M.A.; Alonso, S. A low-cost open source hardware in control education. Case study: Arduino-feedback Ms-150. IFAC-PapersOnLine 2015, 48, 117-122. [CrossRef]

11. Schelly, C.; Anzalone, G.; Wijnen, B.; Pearce, J.M. Open-source 3-D printing technologies for education: Bringing additive manufacturing to the classroom. J. Vis. Lang. Comput. 2015, 28, 226-237. [CrossRef]

12. Athani, S.; Tejeshwar, C.H.; Patil, M.M.; Patil, P.; Kulkarni, R. Soil moisture monitoring using IoT enabled arduino sensors with neural networks for improving soil management for farmers and predict seasonal rainfall for planning future harvest in North Karnataka-India. In Proceedings of the 2017 International Conference on I-SMAC (IoT in Social, Mobile, Analytics and Cloud), Palladam, India, 10-11 February 2017; pp. 43-48. [CrossRef]

13. Bitella, G.; Rossi, R.; Bochicchio, R.; Perniola, M.; Amato, M. A novel low-cost open-hardware platform for monitoring soil water content and multiple soil-air-vegetation parameters. Sensors 2014, 14, 19639-19659. [CrossRef]

14. Patil, A.; Beldar, M.; Naik, A.; Deshpande, S. Smart farming using Arduino and data mining. In Proceedings of the 2016 3rd International Conference on Computing for Sustainable Global Development (INDIACom), New Delhi, India, 16-18 March 2016; pp. 1913-1917.

15. Mesas-Carrascosa, F.J.; Santano, D.V.; Meroño, J.E.; De La Orden, M.S.; García-Ferrer, A. Open source hardware to monitor environmental parameters in precision agriculture. Biosyst. Eng. 2015, 137, 73-83. [CrossRef]

16. Wishkerman, A.; Wishkerman, E. Application note: A novel low-cost open-source LED system for microalgae cultivation. Comput. Electron. Agric. 2017, 132, 56-62. [CrossRef]

17. Open-Source CNC Farming. Available online: https://farm.bot (accessed on 27 November 2019).

18. Ferdoush, S.; Li, X. Wireless sensor network system design using raspberry pi and Arduino for environmental monitoring applications. Procedia Comput. Sci. 2014, 34, 103-110. [CrossRef]

19. Lockridge, G.; Dzwonkowski, B.; Nelson, R.; Powers, S. Development of a low-cost arduino-based sonde for coastal applications. Sensors 2016, 16, 528. [CrossRef]

20. Steiniger, S.; Hay, G.J. Free and open source geographic information tools for landscape ecology. Ecol. Inform. 2009, 4, 183-195. [CrossRef]

21. Gad, H.E.; Gad, H.E. Development of a new temperature data acquisition system for solar energy applications. Renew. Energy 2015, 74, 337-343. [CrossRef]

22. Hars, A. Working for free? Motivations of participating in open source projects. In Proceedings of the 34th Hawaii International Conference on System Sciences, Maui, HI, USA, 6 January 2001; pp. 1-9. [CrossRef]

23. List of Open-Source Hardware Projects. Available online: https://en.wikipedia.org/wiki/List_of_open-source_ hardware_projects (accessed on 3 March 2020).

24. List of Open-Source Computing Hardware. Available online: https://en.wikipedia.org/wiki/List_of_opensource_computing_hardware (accessed on 3 March 2020).

25. What Is Arduino? Available online: https://www.arduino.cc/en/Guide/Introduction (accessed on 15 March 2020).

26. Mardonova, M.; Choi, Y. Toward Open-Source Hardware and Software for the Mining Industry: A Case Study of Low-Cost Environmental Monitoring System for Non-Metallic Underground Mines. Min. Metall. Explor. 2019, 36, 657-674. [CrossRef]

27. Kim, S.M. Review of Internet of Things and Open-Source Hardware Technologies Use in the Mining Industry. J. Korean Soc. Miner. Energy Resour. Eng. 2019, 56, 447-456. [CrossRef]

28. Jo, B.W.; Khan, R.M.A. An event reporting and early-warning safety system based on the internet of things for underground coal mines: A case study. Appl. Sci. 2017, 7, 925. [CrossRef]

29. Alam, M.M.; Chakraborty, P.P.; Biswas, S.; Islam, A.J. Design of an intelligent helmet for mine workers. In Proceedings of the International Conference on Mechanical Engineering and Renewable Energy 2015, Chittagong, Bangladesh, 26-29 November 2015; pp. 1-5.

30. Sakthi, S.; Niresh, J.; Neelakrishnan, S. Adaptive Admittance Control for Autonomous Loading of Load Haul Dumper in Underground Coal Mining. In Proceedings of the 5th International Conference on Mechatronics and Robotics Engineering, Rome, Italy, 16-19 February 2019; pp. 73-77. [CrossRef] 
31. A Comparison of Popular Arduino Boards. Available online: https://maker.pro/arduino/tutorial/acomparison-of-popular-arduino-boards (accessed on 10 March 2020).

32. Matin, M.A.; Islam, M.M. Overview of wireless sensor network. In Wireless Sensor Networks-Technology and Protocols; InTech: Rijeka, Croatia, 2012. [CrossRef]

33. Naidu, K.P.S.S.V.; Visalakshi, P.; Chowdary, P.C. Coal mine safety system using Li-Fi technology. Int. J. Adv. Res. Ideas Innov. 2019, 5, 1288-1291.

34. Anitha, K.; Seshagiri, T. Implementation of Wireless Sensor in Coal Mine Safety System using ZigBee. Int. Res. J. Eng. Tech. 2019, 6, 1467-1472.

35. Srivastava, S.K. Real Time Monitoring System for Mine Safety Using Wireless Sensor Network (Multi-Gas Detector). Master's Thesis, National Institute of Technology Rourkela, Rourkela, India, 2015.

36. Kugan, R.S.; Gobi, K.R.; Mohan, M.; Gowtham, V.; Praveena, R. Coal mine monitoring and alert system with data acquisition. Int. J. Innov. Res. Adv. Eng. 2019, 6, 186-191.

37. Bhagat, N.B. Wireless Surveillance and Safety System for Mine Workers Using ZigBee. Ph.D. Thesis, Nagpur University, Nagpur, Maharashtra, 2016.

38. Ünsal, E.; Akkan, T.; Akkan, L.Ö.; Çebi, Y. Power management for Wireless Sensor Networks in underground mining. In Proceedings of the 24th Signal Processing and Communication Application Conference (SIU), Zonguldak, Turkey, 16-19 May 2016; pp. 1053-1056. [CrossRef]

39. Nath, S.; Dey, A.; Pachal, P.; Chowdhury, S.R.; Sing, J.K.; Sarkar, S.K. Nano Structured Gas Sensing Device and Its Application in Underground Mines. In Proceedings of the 2018 IEEE Electron Devices Kolkata Conference (EDKCON), Kolkata, India, 24-25 November 2018; pp. 445-449. [CrossRef]

40. Shah, A.; Patel, D.; Desai, P. IoT enabled worker safety system. J. Inf. Comput. Sci. 2019, 9, 732-744.

41. Rajalakshmi, R.; Vidhya, J. Toxic Environment Monitoring Using Sensors Based on Arduino. In Proceedings of the 2019 IEEE International Conference on System, Computation, Automation and Networking (ICSCAN), Pondicherry, India, 29-30 March 2019; pp. 1-6. [CrossRef]

42. Sudila, N.; Elvitigala, C.S.; Wijebandara, L.R.; Gamage, G.S.; Jayakody, J.A.R.S.; Yapa, K.G.D.T. A IoT Proactive Disaster Management System for Mines. In Proceedings of the 18th International Symposium on Advanced Intelligent Systems (ISIS2017), Daegu, Korea, 11-14 October 2017; pp. 1-4.

43. Durán, C.A.; Goméz, P.M.; Acosta, R.R. Wireless Smell System for Hazardous Gases Detection. Preprints 2018, 1-14. [CrossRef]

44. Jo, B.; Khan, R.M.A. An internet of things system for underground mine air quality pollutant prediction based on azure machine learning. Sensors 2018, 18, 930.

45. Mondal, B.; Meetei, M.S.; Das, J.; Chaudhuri, C.R.; Saha, H. Quantitative recognition of flammable and toxic gases with artificial neural network using metal oxide gas sensors in embedded platform. Eng. Sci. Technol. Int. J. 2015, 18, 229-234. [CrossRef]

46. Rodriguez-Diaz, O.O.; Novella-Rodriguez, D.F.; Witrant, E.; Franco-Mejía, E. Benchmark for analysis, modeling and control of ventilation systems in small-scale mine. In Proceedings of the 2019 International Conference on Control, Automation and Diagnosis (ICCAD), Grenoble, France, 2-4 July 2019; pp. 1-6. [CrossRef]

47. Adjiski, V.; Despodov, Z.; Serafimovski, D.; Mijalkovski, S. Methodology for evaluation of the evacuation time in case of fire in underground mines. In Proceedings of the XII Стручно советувањеодобласта на подземната и површинската експлоатација (Подекс-Повекс2019), Strumica, Macedonia, 1-3 November 2019; pp. 12-21.

48. Adjiski, V.; Despodov, Z.; Serafimovski, D.; Mijalkovski, S. System for prediction of carboxyhemoglobin levels as an indicator for on-time installation of self-contained self-rescuers in case of fire in underground mines. Geosci. Eng. 2019, 65, 23-37. [CrossRef]

49. Pop, E.; Ilcea, G.I.; Popa, I.A.; Bogdanffy, L. Increasing the Safety of People Activity in Aggressive Potential Locations, Analyzed through the Probability Theory, Modeling/Simulation and Application in Underground Coal Mining. Engineering 2019, 11, 93-106. [CrossRef]

50. Jayanthu, S.; Karthik, G.; Yadav, D.K. Current Trends in Slope Stability Monitoring in Opencast Mines Vis-À-Vis Time Domain Reflectometry. In Proceedings of the Current Practices in Mining \& Allied Industries, Keonjhar, India, 23-24 September 2017; pp. 62-70.

51. Karthik, G.; Jayanthu, S. Selection of suitable location and method for installation of TDR in opencast mine-an experimental approach. Math. Model. Eng. Probl. 2018, 5, 256-259. [CrossRef] 
52. Jayanthu, S.; Karthik, G. Development of Effective Technology for Online Slope Monitoring in Opencast Mines-R\&D Initiative. In Proceedings of the Workshop on Emerging Mining Technologies and Low-Carbon Footprints with Waste Management, Vigyan Bhawan, New Delhi, India, 13-14 February 2017; pp. 1-11.

53. Jayanthu, S.; Karthik, G.; Shohood A, P.M.G. Development of Indigenous Wireless Tiltmeter for Slope Stability Monitoring in Opencast Mines. In Proceedings of the Seminar on Make in India Initiatives in Mining, Satna, India, 23 December 2016; pp. 1-7.

54. Prashanth, R.; Nimaje, D.S. Development of blast-induced ground vibration wireless monitoring system. In Proceedings of the 39th Application of Computers and Operations Research in the Mineral Industry (APCOM 2019), Wroclaw, Poland, 4-6 June 2019; pp. 1-8. [CrossRef]

55. Tiwari, S.; Arya, A.; Chatterjee, A.; Mishra, P.K.; Banerjee, G. Development of laboratory scale wireless borehole extensometer for underground mines. In Proceedings of the Seminar on Technological Advancement and Emerging Mining Methods (TAEMM 2018), Dhanbad, India, 24-25 August 2018; pp. 252-255.

56. Alzahrani, A.A.M. Detection of Mine Roof Failure Using Inexpensive LiDAR Technology. Master's Thesis, Missouri University of Science and Technology, Rolla, MO, USA, 2017.

57. Mukherjee, M.; Jayanthu, S. Innovative Application of T-Ray Imaging Unit for Crack Detection and Mine Safety-An Appraisal for Experimental Trial. In Proceedings of the 2nd National Conference on Current Practices in Mining and Allied Industries (CPMAI 2018), Keonjhar, Odisha, India, 6-7 October 2018; pp. 1-14.

58. Mardonova, M.; Choi, Y. Review of Wearable Device Technology and Its Applications to the Mining Industry. Energies 2018, 11, 547. [CrossRef]

59. Majee, A. IoT Based Automation of Safety and Monitoring System Operations of Mines. Int. J. Elect. Electron. Eng. 2016, 3, 17-21. [CrossRef]

60. Harshitha, K.; Sreeja, K.; Manusha, N.; Harika, E.; Rao, P.K. ZigBee based intelligent helmet for coal miners safety purpose. Int. J. Innov. Technol. 2018, 6, 403-406.

61. Roja, P.; Srihari, D. Iot based smart helmet for air quality used for the mining industry. Int. J. Res. Sci. Eng. Technol. 2018, 4, 514-521.

62. Bhuttoa, G.M.; Daudpotoa, J.; Jiskanib, I.M. Development of a wearable safety device for coal miners. Int. J. Chem. Env. Eng. 2016, 7, 225-229.

63. Noorin, M.; Suma, K.V. IoT based wearable device using WSN technology for miners. In Proceedings of the 3rd IEEE International Conference on Recent Trends in Electronics, Information \& Communication Technology (RTEICT), Bangalore, India, 18-19 May 2018; pp. 992-996. [CrossRef]

64. Priyadarsini, V.; Verma, A.; Singh, M.; Netam, S.; Chandrakar, D. LabVIEW Based Real Time Monitoring System for Coal Mine Worker. J. Digit. Signal Process. 2018, 6, 1-6. [CrossRef]

65. Dudwadkar, A.; Parkhi, N.; Kulkarni, M.; Shah, H.; Gupta, R. Wireless Mine Surveillance with Data Logging. Int. J. Adv. Res. Elect. Electron. Instru. Eng. 2016, 5, 2401-2406. [CrossRef]

66. Oliveira, V.A.D.J.; Marques, E.; de Lemos Peroni, R.; Maciel, A. Tactile interface for navigation in underground mines. In Proceedings of the 2014 XVI Symposium on Virtual and Augmented Reality, Piata Salvador, Brazil, 12-15 May 2014; pp. 230-237. [CrossRef]

67. Dewarkar, A.; Lengure, R.; Thool, S.; Borakhade, S. Smart Device for Security of Coal Mine Workers. Int. J. Innov. Res. Technol. 2019, 5, 351-353.

68. Sanjay, B.S.; Dilip, K.A.; Balasaheb, T.A.; KinnuKumar, S.; Chandrabhushan, P.; Saware, N.P. Smart Helmet Using ZigBee. Int. J. Innov. Res. Technol. 2019, 6, 144-148.

69. Azizi, M.; Tarshizi, E. Autonomous control and navigation of a lab-scale underground mining haul truck using LiDAR sensor and triangulation-feasibility study. In Proceedings of the 2016 IEEE Industry Applications Society Annual Meeting, Portland, OR, USA, 2-6 October 2016; pp. 1-6. [CrossRef]

70. Ledange, S.M.; Mathurkar, S.S. Robot based wireless monitoring and safety system for underground coal mines using ZigBee. Int. J. Electron. Commun. Eng. 2016, 3, 23-26. [CrossRef]

71. Salazar, R.; Conislla, O.; Cornejo, J. Design and Construction of a Remotely Controlled Truck Robot for Detecting Harmful and Flammable Gases in Underground Mining. Available online: http://acreditacion.uni.edu.pe/wp-content/uploads/2017/05/Design-and-Construction-of-a-RemotelyControlled-Truck-Robot-for-Detecting-Harmful-and-Flammable-Gases-in-Underground-Mining.pdf (accessed on 7 April 2020). 
72. Cekova, K.; Martinovska Bande, C.; Velkova, A.; Stojkovic, N. Mobile Sensor System for Detection of Toxic Gases in Mines. In Proceedings of the 10th ICT Innovations, Engineering and Life Sciences WEB, Metropol Lake Resort, Ohrid, Macedonia, 17-19 September 2018; pp. 112-123.

73. Bai, L.; Huang, X.; Liu, X.; Gao, H.; Huang, M. Mechanical-electrical-pneumatic systematic design exploration of hexapod robot experimental prototype. J. Eng. 2019, 23, 8932-8936. [CrossRef]

74. Kumar, S.S.; Jabannavar, S.S.; Shashank, K.R.; Nagaraj, M.; Shreenivas, B. Localization and tracking of unmanned vehicles for underground mines. In Proceedings of the 2017 Second International Conference on Electrical, Computer and Communication Technologies (ICECCT), Coimbatore, India, 22-24 February 2017; pp. 1-4. [CrossRef]

75. Alvarado, M.; Gonzalez, F.; Fletcher, A.; Doshi, A. Towards the development of a low cost airborne sensing system to monitor dust particles after blasting at open-pit mine sites. Sensors 2015, 15, 19667-19687. [CrossRef] [PubMed]

76. Martin, P.G.; Payton, O.D.; Fardoulis, J.S.; Richards, D.A.; Scott, T.B. The use of unmanned aerial systems for the mapping of legacy uranium mines. J. Environ. Radioactiv. 2015, 143, 135-140. [CrossRef] [PubMed]

77. Mitchell, J.; Marshall, J.A. Towards a novel auto-rotating lidar platform for cavity surveying. Tunn. Undergr. Space Technol. 2020, 97, 103260. [CrossRef]

78. Videla, A.R.; Morales, R.; Saint-Jean, T.; Gaete, L.; Vargas, Y.; Miller, J.D. Ultrasound treatment on tailings to enhance copper flotation recovery. Miner. Eng. 2016, 99, 89-95. [CrossRef]

79. Deen, K.M.; Asselin, E. Integration of $\mathrm{Cu}$ extraction and $\mathrm{Zn}$ electrowinning processes for energy storage. J. Clean. Prod. 2020, 253, 119779. [CrossRef]

80. Liu, X.; Li, X.; Li, F.; Zhao, G.; Qin, Y. 3D cavity detection technique and its application based on cavity auto scanning laser system. J. Central South Univ. Technol. 2008, 15, 285-288. [CrossRef]

(C) 2020 by the authors. Licensee MDPI, Basel, Switzerland. This article is an open access article distributed under the terms and conditions of the Creative Commons Attribution (CC BY) license (http://creativecommons.org/licenses/by/4.0/). 